\title{
A review of exenatide as adjunctive therapy in patients with type 2 diabetes
}

This article was published in the following Dove Press journal:

Drug Design, Development and Therapy

9 September 2009

Number of times this article has been viewed

\section{Gisela I Robles \\ Devada Singh-Franco}

Nova Southeastern University, College of Pharmacy, Health

Professions Division, Fort Lauderdale, FL, USA
Correspondence: Gisela I Robles Nova Southeastern University, College of Pharmacy, Health Professions Division, 3200 South University Drive, Fort Lauderdale, FL 33328, USA

Tel + I 954-262-I362

Email rgisela@nova.edu
Background: Incretin glucagon-like peptide-1 (GLP-1) is a hormone released from cells in the gastrointestinal tract (GI), leading to glucose-dependent insulin release from the pancreas. It also suppresses postprandial hyperglycemia, glucagon secretion and slows gastric emptying. Exenatide (EXE), a functional analog of human GLP-1, was approved by the US FDA in April 2005.

Objective: This article reviews current primary literature on the clinical efficacy and safety of EXE in the treatment of type 2 diabetes mellitus (DM) and describes the pharmacokinetics, pharmacodynamics, dosing and administration of EXE.

Methods: English-language articles were identified through a search of MEDLINE (1966 to March 2009), International Pharmaceutical Abstracts (1970 to present), and Cochrane Database of Systemic Reviews (1995 to March 2009). Search terms included EXE, diabetes mellitus, postprandial hyperglycemia, gastric emptying, glucagon, pharmacokinetics and pharmacodynamics. Articles were selected for review if their designs were randomized, blinded and of controlled design that focused on clinical outcomes of patients with type $2 \mathrm{DM}$.

Results: EXE is administered subcutaneously in the thigh, abdomen or upper arm within the 60-minute period before the morning and evening meals. Its $\mathrm{C}_{\max }$ is reached within 2.1 hours, and its $\mathrm{T}_{1 / 2}$ in 2.4 hours. EXE's metabolism is primarily through the kidneys. For the patients who received EXE $10 \mu \mathrm{g}$ SC BID in three, 30-week, placebo-controlled studies with background sulfonylureas (SUs), metformin (MET), or SU + MET, there were significant reductions in $\mathrm{HbA}_{1 \mathrm{c}}(0.77$ to $0.86 \%)$, fasting plasma glucose $(0.6 \mathrm{mmol} / \mathrm{L})$ and body weight $(1.6$ to $2.8 \mathrm{~kg})$ $(P \leq 0.05$ vs $\mathrm{PCB})$ that were sustained in patients who completed two open-label phase trials with an additional 52 weeks of therapy. The use of thiazolidinediones was associated with a slight advantage over EXE in improving $\mathrm{HbA}_{1 \mathrm{c}}$ along with increased weight gain; those who received EXE lost weight, but experienced more GI adverse effects. Patients who received EXE lost significant body weight while patients who received insulin gained weight. Patients receiving insulin had lower fasting, prelunch and predinner glucose excursions while patients in the EXE groups had lower postprandial glucose levels. Nausea was most frequently $(>20 \%)$ reported in patients receiving the highest dose of EXE (10 $\mu \mathrm{g}$ SC BID vs $5 \mu \mathrm{g}$ SC BID).

Conclusions: EXE at the dose of $10 \mu \mathrm{g}$ SC BID has been proven to decrease $\mathrm{HbA}_{1 \mathrm{c}}$ by $1.3 \% \pm 0.1 \%$ and decrease body weight by up to $5.3 \pm 0.8 \mathrm{~kg}$ at week 82 . Nausea was the most frequently reported adverse event $(>20 \%)$ especially in patients being treated with EXE $10 \mu \mathrm{g}$ SC BID. EXE can be safely added to MET therapy, SU therapy or MET + SU combination to effectively target glycemic goals in patients with type $2 \mathrm{DM}$. Long-term, head-to-head studies assessing the effect of the EXE \pm oral agents/insulins in patients with $\mathrm{HbA}_{\mathrm{lc}} \geq 10 \%$ are still needed to fully clarify the role of EXE in poorly controlled patients with type $2 \mathrm{DM}$.

Keywords: exenatide, glucagon-like peptide-1, incretin, pharmacokinetics, pharmacodynamics, pharmacoeconomic, postprandial hyperglycemia, gastric emptying, glucagon 


\section{Introduction}

Diabetes mellitus (DM) comprises a group of chronic metabolic disorders characterized by hyperglycemia as a result of complete lack of insulin, a relative lack of insulin or insulin resistance. DM may result in long-term microvascular (ie, retinopathy and nephropathy), macrovascular (ie, cardiovascular disease) and neuropathic complications. In the US, it is estimated that 23.6 million people ( $7.8 \%$ of the population) have diabetes with the highest prevalence among American Indians/Alaska Natives (16.5\%), African Americans (11.8\%), and Hispanics (10.4\%). ${ }^{1}$ The increased cardiovascular risk associated with DM contributes to it being the sixth leading cause of death in the US. ${ }^{1}$ For every $1 \%$ increase in glycosylated hemoglobin $\left(\mathrm{HbA}_{1 \mathrm{c}}\right)$ above $5 \%$, there is a $20 \%$ epidemiological increase in cardiovascular risk. ${ }^{2}$ The financial impact of DM in 2007 was estimated to be US $\$ 174$ billion (direct medical costs and indirect costs resulting from lack of employee productivity). ${ }^{3}$ Worldwide, the total number of people with DM is projected to increase from 171 million in 2000 to 366 million in 2030. ${ }^{4}$ These statistics suggest that the "diabetes epidemic" is real and there is an important need to allocate resources to educate patients about prevention, lifestyle modifications, and proper usage of diabetes medications.

The prevention of health complications associated with DM through effective glucose control $\left(\mathrm{HbA}_{1 \mathrm{c}}<7\right)$ continues to be the primary objective of DM management. ${ }^{5}$ The treatment of type 2 DM consists of life-style changes (diet and exercise) and the use of oral hypoglycemic agents, insulin sensitizers, oral agents that impede hepatic production of glucose, and exogenous insulin. ${ }^{6-8}$ However, hypoglycemia, gastrointestinal (GI) side effects, weight gain, and lack of optimal control of postprandial glucose are limitations that may present with the use of these type 2 DM treatments, preventing patients from reaching glycemic control. ${ }^{9}$ As a result, there is an interest in therapies that control blood glucose by alternative physiological mechanisms that do not significantly change patients weight, induce hypoglycemia or GI side effects, ${ }^{9}$ In April of 2005, the FDA approved exenatide (EXE) as the first incretin mimetic injection formulation to treat type $2 \mathrm{DM}$. This article compiles results of recently published primary literature on the efficacy and safety of EXE injection. Additional topics discussed in this article include dosing, administration, drug interactions, pharmacokinetics, and pharmacodynamics of EXE injection.

\section{Materials and methods}

English-language articles were identified through a search of MEDLINE (1966 to March 2009), International Pharmaceutical
Abstracts (1970 to present), and Cochrane Database of Systemic Reviews (1995 to March 2009). Search terms included EXE, diabetes mellitus, postprandial hyperglycemia, gastric emptying, glucagon, pharmacokinetics and pharmacodynamics. Articles were selected for review if their designs were randomized, blinded (investigator, participant or both), and of controlled design that focused in clinical outcomes of patients with type $2 \mathrm{DM}$ by measuring $\mathrm{HbA}_{1 \mathrm{c}}$.

\section{Pathophysiology of diabetes mellitus}

The primary defect in type $1 \mathrm{DM}$ is the absolute lack of insulin production that results from cellular-mediated autoimmune destruction of pancreatic $\beta$-cells. The presence of human leukocyte antigens, islet cell antibodies, insulin antibodies and/or glutamic acid decarboxylase autoantibodies are strong predictors for the development of type $1 \mathrm{DM}^{6}{ }^{6}$ Signs and symptoms of hyperglycemia are present when most patients have lost $90 \%$ of the $\beta$-cell function. The treatment of type $1 \mathrm{DM}$ includes the use of exogenous insulin, diet and exercise. ${ }^{6}$

The primary defects in type $2 \mathrm{DM}$ are pancreatic $\beta$-cell failure, increased insulin resistance and impaired insulin secretion that leads to relative insulin deficiency. ${ }^{6,7}$ Insulin resistance occurs significantly in skeletal muscle and liver. The combination of poor glucose uptake by the tissues and continuous production of glucose by the liver during the ingestion of glucose (fed state) leads to elevations in blood glucose levels. Impaired insulin secretion with progressive loss of pancreatic $\beta$-cells functioning leads to hyperglycemia and lack of sufficient first-phase insulin response to signal the liver to stop producing glucose during the fed state. ${ }^{6}$ Other anomalies found in patients with type 2 DM include the excessive production of glucagon (a hormone produced by the pancreas responsible for carbohydrate metabolism) and impaired incretin hormones response (hormones responsible for stimulating insulin secretion in the presence of glucose). ${ }^{10,11}$ The lack of suppression of postprandial glucagon secretion in patients with type $2 \mathrm{DM}$ is the result of impaired glucose sensing by pancreatic $\alpha$-cells (cells responsible for the pancreatic secretion of glucagon) and/or resistance of pancreatic $\alpha$-cells to the inhibitory actions of insulin. ${ }^{12}$ Glucagon excess in patients with type 2 DM counteracts the action of insulin on glucose metabolism by stimulating glycogenolysis and gluconeogenesis. ${ }^{10,11}$

Incretins are gut hormones that are released from cells in the GI track within minutes after eating, leading 
to glucose-dependent insulin release from the pancreas into the blood. There are two incretin hormones known as glucose-dependent insulinotropic peptide (GIP) and glucagon-like peptide-1 (GLP-1). In type 2 DM, GIP no longer modulates glucose-dependent insulin secretion and there are modest but significant reductions in meal-stimulated circulating levels of GLP-1. ${ }^{13,14}$ EXE is a functional analog of human GLP-1 that binds to and stimulates GLP-1 receptors, thus increasing insulin secretion. Mechanisms by which EXE improves glycemic control include the regulation of glucose-dependent insulin secretion, the suppression of inappropriately high glucagon secretion, the slowing of gastric emptying (which reduces the rate at which meal-delivered glucose appears in the circulation) and the reduction of food intake. ${ }^{15}$ Other EXE glycemic regulatory properties include the effects on increasing $\beta$-cell proliferation and inhibition of $\beta$-cell apoptosis seen primary in animal and small human studies. ${ }^{16-19}$

\section{Exenatide injection}

EXE is approved as an adjunctive subcutaneous therapy to improve glycemic control in patients with type 2 DM who have not achieved adequate glycemic control while taking metformin, a sulfonylurea, a thiazolidinedione, or a combination of these oral agents. ${ }^{20}$ EXE is derived from salivary secretions of the lizard Heloderma suspectum and shares $53 \%$ amino acid sequence identity with human GLP-1 that allows the direct binding to GLP-1 receptors. The in vivo potency of EXE has been shown to be much greater than that of GLP-1 due to EXE's resistance to degradation by dipeptidyl peptidase-IV (enzyme responsible for deactivating incretin hormones). ${ }^{21}$

\section{Pharmacokinetics}

EXE reaches median peak plasma concentrations in 2.1 hours after subcutaneous injection. The mean peak EXE concentration $\left(\mathrm{C}_{\text {max }}\right)$ is $211 \mathrm{pg} / \mathrm{mL}$ and the mean area under the plasma concentration-time curve from time zero to infinity $\left(\mathrm{AUC}_{0 \text {-inf }}\right)$ is $1036 \mathrm{pg} * \mathrm{~h} / \mathrm{mL}$ following subcutaneous administration of a $10 \mu \mathrm{g}$ dose of EXE. The EXE exposure (AUC) increases proportionally over the therapeutic dose range of $5 \mu \mathrm{g}$ to $10 \mu \mathrm{g}$ unlike the $\mathrm{C}_{\text {max }}$ values that increase less proportionally over the same dose range. No differences in EXE exposure are found at the different sites of subcutaneous administration (abdomen, thigh, or arm). EXE is predominantly eliminated by glomerular filtration with subsequent proteolytic degradation. The $t_{1 / 2}$ of EXE is 2.4 hours. These pharmacokinetic characteristics of EXE are independent of the dose. ${ }^{20}$

\section{Special populations}

No pharmacokinetic studies were identified that assessed the effect of race, gender, age, weight or hepatic insufficiency on the pharmacokinetics of EXE. However, in patients with end-stage renal disease that are receiving dialysis, mean EXE clearance is reduced to $0.9 \mathrm{~L} / \mathrm{h}$ compared with $9.1 \mathrm{~L} / \mathrm{h}$ in healthy subjects. ${ }^{20}$ In a study by Linnebjerg et $\mathrm{al}^{22}$ the effects of renal impairment on the pharmacokinetics of a single EXE dose ( 5 and $10 \mu \mathrm{g}$ ) administered $15 \mathrm{~min}$ prior to a standardized breakfast in patients classified as having normal renal function (Cockcroft-Gault creatinine

Table I Exenatide characteristics ${ }^{20,51}$

\begin{tabular}{|c|c|}
\hline Indication & $\begin{array}{l}\text { Adjunctive therapy in patients with type } 2 \text { diabetes who have not reached glycemic goals despite receiving } \\
\text { treatment with metformin, sulfonylurea, a thiazolidinedione or a combination of these oral agents }\end{array}$ \\
\hline Mechanism of action & $\begin{array}{l}\text { Regulates glucose-dependent insulin secretion, suppresses inappropriately high glucagon secretion, slows down gastric } \\
\text { emptying (reduces the rate at which meal-delivered glucose appears in the circulation) and reduces food intake }\end{array}$ \\
\hline Dosage and administration & $\begin{array}{l}\text { Starting dose }=5 \mu \mathrm{g} \\
\text { Target dose }=5 \text { or } 10 \mu \mathrm{g} \\
\text { Route of administration = subcutaneous injection in the thigh, abdomen or upper arm } \\
\text { Frequency and timing of administration = twice daily within the } 60 \text {-min period before the morning and evening } \\
\text { meals (or before the two main meals of the day, approximately } 6 \text { hours or more apart) }\end{array}$ \\
\hline Adverse events & $\begin{array}{l}\text { Gastrointestinal = nausea, vomiting, diarrhea, pancreatitis (rare) } \\
\text { Hypoglycemia (especially in patients taking sulfonylurea concomitantly) }\end{array}$ \\
\hline Other properties & $\begin{array}{l}\text { Pregnancy category } C \text { (there are no adequate and well-controlled studies in pregnant women) } \\
\text { Suppresses appetite } \\
\text { Patients may lose weight } \\
\text { Caution should be exercised in patients with impaired renal function }\end{array}$ \\
\hline Cost & $\begin{array}{l}\text { Average wholesale price: } \\
\text { I. } 2 \mathrm{~mL}(5 \mu \mathrm{g} / 0.2 \mathrm{~mL}) \text { prefilled pen }=\text { US } \$ 240.84 \\
2.4 \mathrm{~mL}(10 \mu \mathrm{g} / 0.4 \mathrm{~mL}) \text { prefilled pen }=\text { US } \$ 282.63\end{array}$ \\
\hline
\end{tabular}


clearance $[\mathrm{CrCl}]>80 \mathrm{~mL} / \mathrm{min}, \mathrm{N}=8$ ), mild renal impairment ( $\mathrm{CrCl} 51$ to $80 \mathrm{~mL} / \mathrm{min}, \mathrm{N}=8)$, moderate renal impairment ( $\mathrm{CrCl} 31$ to $50 \mathrm{~mL} / \mathrm{min}, \mathrm{N}=7$ ) or end stage renal disease $(E S R D$, patients receiving hemodialysis for at least 1 month before screening, $\mathrm{N}=8$ ) were evaluated.

From the 31 participants (16 out of 31 were male), only one subject had type $2 \mathrm{DM}$ that was controlled with diet. All patients in the normal renal function group (mean [ $\pm \mathrm{SD}]$ age, 46 [5.5] years; mean BMI, 25.7 [4.08] kg/m²; mean [range] $\mathrm{CrCl}, 111 \mathrm{~mL} / \mathrm{min}$ [ 83 to 156$]$ ) and in the mild renal impairment group (mean [ $\pm \mathrm{SD}]$ age, 56 [9.9] years; mean BMI, 25.5 [2.77] kg/m²; mean [range] $\mathrm{CrCl}, 68 \mathrm{~mL} / \mathrm{min}$ [60 to 78]) received a single dose of EXE $10 \mu \mathrm{g}$. Five out of the 7 patients with moderate renal impairment (mean [ $\pm \mathrm{SD}$ ] age, 64 [9.6] years; mean BMI, 27.2 [3.02] kg/m²; mean [range] $\mathrm{CrCl}, 45 \mathrm{~mL} / \mathrm{min}$ [34 to 50]) and all 8 patients with ESRD (mean [ \pm SD] age, 52 [18.3] years; mean BMI, 23.7 [3.29] kg/m²) received a single dose of EXE $5 \mu \mathrm{g}$. After investigators combined the data from this small sample size study with previously available data from 4 single-dose crossover studies, researchers found that compared with participants in the normal renal function group: 1) EXE clearance was significantly reduced by $36 \%$ in the moderate renal impairment group (least squares geometric mean $\left[\mathrm{CL}_{\mathrm{p}} / \mathrm{F}\right], 8.14$ vs $\left.5.19 \mathrm{~L} / \mathrm{h}, P=0.008\right)$ and by $84 \%$ in the

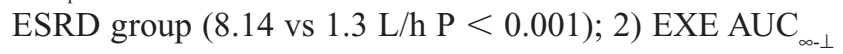
significantly increased 1.63 times $(P=0.003)$ in the moderate renal impairment group and 6.24 times $(P<0.001)$ in the

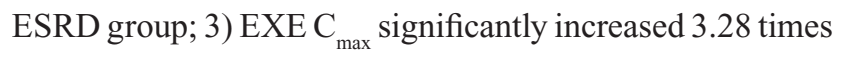
$(P<0.001)$ in the ESRD group and 4$)$ antiemetic medications were administered to 7 out of 8 participants with ESRD because severe or longer duration nausea compared with 1 out of 8 participants in the normal renal function group. ${ }^{22}$ The manufacture of EXE recommends caution when using EXE in patients with ESRD secondary to changes in the pharmacokinetics of EXE and decrease tolerability. ${ }^{20}$

\section{Drug interactions}

EXE slows gastric emptying and therefore may reduce the rate of absorption of certain oral medications. Patients should be advised to take medications that depend on threshold concentrations for efficacy (ie, oral contraceptives and antibiotics) at least 1 hour before injecting EXE. Additionally, caution should be exercised when taking medications that require rapid GI absorption while using EXE. ${ }^{20}$

In a randomized, single-blind, placebo-controlled, 6-way crossover study by Blase et $\mathrm{al}^{23}$ the effects of EXE $10 \mu \mathrm{g}$ on the pharmacokinetics of acetaminophen $1000 \mathrm{mg}$ were assessed $(\mathrm{N}=39$ healthy subjects $)$. Acetaminophen $\mathrm{AUC}_{0-12 \mathrm{~h}}$ levels were reduced by $11 \%$ to $24 \%$ and acetaminophen $\mathrm{C}_{\max }$ were reduced by $37 \%$ to $56 \%$ depending on the coadministration times with $\operatorname{EXE}(-1,0,+1,+2$ and +4 hours $)$.

In an open-label study by Kothare et $\mathrm{al}^{24}$ the effects of EXE $10 \mu \mathrm{g}$ twice daily (BID) on the steady-state pharmacokinetics of oral digoxin $(0.5$ and $0.25 \mathrm{mg})$ were assessed $(\mathrm{N}=21$ healthy male subjects). A $17 \%$ reduction of digoxin $\mathrm{C}_{\max }$ was noted. However, peak concentrations of digoxin remained within the therapeutic concentration range.

In an open-label, 2-period, fixed-sequence study by Soon et $\mathrm{al}^{25}$ the effects of EXE $10 \mu \mathrm{g}$ BID on the pharmacokinetic and pharmacodynamics of warfarin $25 \mathrm{mg}$ one-time dose ( $\mathrm{N}=16$ healthy subjects) were evaluated. When comparing R-warfarin + EXE with $\mathrm{R}$-warfarin alone, EXE did not significantly alter the $\mathrm{AUC}_{0 \text {-inf }}$ $(110,425 \mathrm{~h} \cdot \mathrm{ng} / \mathrm{mL}$ vs $99,411 \mathrm{~h} \cdot \mathrm{ng} / \mathrm{mL})$ or $\mathrm{C}_{\text {max }}(1345 \mathrm{ng} / \mathrm{mL}$ vs $1282 \mathrm{ng} / \mathrm{mL}$ ) of warfarin. No significant alterations were found when comparing the maximum-observed International Normalized Ratio (INR ${ }_{\text {max }}, 1.72$ vs 1.95 ) or time to INR $_{\text {max }}$ (24.05 to $48.20 \mathrm{~h}$ vs 36.00 to $48.63 \mathrm{~h}$ ). However, spontaneous postmarketing reports have noted increases in INR levels with the combined use of warfarin and EXE that in some cases had been associated with bleeding. ${ }^{20}$

\section{Pharmacodynamics Effect on $\beta$-cell functioning} and insulin secretion

Bunck et $\mathrm{al}^{26}$ conducted a 52-week, randomized study in Sweden, Finland and the Netherlands to assess the effects of EXE $(\mathrm{N}=36$; mean [ $\pm \mathrm{SD}$ ] age, 58.4 [1.4] years; mean weight, 90.6 [2.1] kg; mean $\mathrm{HbA}_{1 \mathrm{c}}, 7.6 \%$ [0.1\%]) and insulin glargine $(\mathrm{N}=33$; mean [ $\pm \mathrm{SD}]$ age, 58.3 [1.3] years; mean weight, 92.4 [2.4] kg; mean $\mathrm{HbA}_{1 \mathrm{c}}, 7.4 \%$ [0.1\%]) on type 2 DM patients' $\beta$-cell function, glycemic control, body weight and safety. Patients randomized to EXE received an initial dose of $5 \mu \mathrm{g}$ BID, injected $15 \mathrm{~min}$ before breakfast and dinner for 4 weeks and $10 \mu \mathrm{g}$ BID for the remaining 48 weeks of the study. For patients in the EXE group with $\mathrm{HbA}_{1 \mathrm{c}} 7.1 \%$ to $7.5 \%$ in 2 consecutive visits or $\mathrm{HbA}_{1 \mathrm{c}} \geq 7.6 \%$ at any visit, EXE was titrated to a maximum dose of $20 \mu \mathrm{g}$ TID. Patients randomized to insulin glargine were started with 10 units at bedtime and were instructed to titrate dose upward or downward based on their self-monitored blood glucose levels and pre-specified algorithm. Insulin secretion and sensitivity was measured during a combined euglycemic-hyperinsulinemic and 
hyperglycemic clamp procedures using arginine prior to randomization, followed by 52 weeks of active therapy and a 4-week off therapy period. After 52 weeks of EXE treatment, C-peptide secretion in response to $15 \mathrm{mmol} / \mathrm{L}$ of glucose $(\mathrm{nmol} * \mathrm{~min} / \mathrm{L})$ at phase 1 (mean difference between groups, $\left.\mathrm{AUC}_{180-190 \min }=1.53 \pm 0.11\right)$ and phase 2 (mean difference between groups, $\mathrm{AUC}_{190-260 \mathrm{~min}}=2.85 \pm 0.22$ ) were statistically significantly greater than in the insulin glargine group, $P<0.0001$. Similarly, in the EXE group, the C-peptide response to arginine (mean difference $\mathrm{AUC}_{260-270 \mathrm{~min}}=2.46 \pm 0.20$ ) at $15 \mathrm{mmol} / \mathrm{L}$ of glucose concentration $(\mathrm{nmol} \cdot \mathrm{min} / \mathrm{L})$ was statistically significantly greater than in the insulin glargine group, $P<0.0001$.

Fehse et $\mathrm{al}^{27}$ evaluated the effects of EXE (bolus $=50 \mathrm{ng} / \mathrm{min}$ for $30 \mathrm{~min}$ and $25 \mathrm{ng} / \mathrm{min}$ for $270 \mathrm{~min}$ ) on insulin, C-peptide and plasma glucagon secretions in patients with type $2 \mathrm{DM}$. Thirteen patients with type 2 DM underwent two experiments: 1) saline infusion on day 2; and 2) IV EXE on day 4 (mean [ $\pm \mathrm{SD}$ ] age, 56 [7] years; mean BMI, $31.7[2.4] \mathrm{kg} / \mathrm{m}^{2}$; mean $\mathrm{HbA}_{1 \mathrm{c}}, 6.6 \%$ [0.7\%]). Ten healthy patients (control) received saline IV on day 2 (mean $[ \pm \mathrm{SD}$ ] age, 57 [9] years; mean BMI, 32 [3] kg/m²). All oral anti-glycemic agents were held during the study duration. An insulin infusion (or saline in the control group) was administered before the EXE infusion in order to maintain the experimental group (type 2 DM patients) with fasting plasma glucose readings of 79 to $101 \mathrm{mg} / \mathrm{dL}$. The IV infusion of EXE was started at 10:00 h (after $240 \mathrm{~min}$ of the insulin infusion and $180 \mathrm{~min}$ before the glucose bolus infusion) and the glucose bolus $(0.3 \mathrm{~g} / \mathrm{kg}$ body weight as $50 \%$ glucose in water) was administered at the 13:00 h. Significantly higher plasma insulin $\mathrm{AUC}_{0-10 \text { min }}$, $\mathrm{AUC}_{10-120 \min }$ and $\mathrm{AUC}_{0-120}$ were observed during the EXE infusion in type $2 \mathrm{DM}$ patients $(655 \pm 116,6923 \pm 941$, $7623 \pm 1040 \mathrm{mU} \cdot \mathrm{min} / \mathrm{L}$ ) compared with the saline infusion in the same type $2 \mathrm{DM}$ patients $(212 \pm 38,2611 \pm 355$, $2830 \pm 386 \mathrm{mU} \cdot \mathrm{min} / \mathrm{L}), P<0.0001$. Similarly, a significantly higher C-peptide concentration $\mathrm{AUC}_{0-10 \mathrm{~min}}, \mathrm{AUC}_{10-120 \mathrm{~min}}$ and $\mathrm{AUC}_{0-120}$ were observed during the EXE infusion (52 \pm 6 , $908 \pm 65,961 \pm 70 \mathrm{ng} \cdot \mathrm{min} / \mathrm{L})$ compared with the saline infusion $(26 \pm 3,514 \pm 37,541 \pm 39 \mathrm{ng} \cdot \mathrm{min} / \mathrm{L}), P<0.0001$. Comparable suppression on plasma glucagon concentrations was observed while patients with type $2 \mathrm{DM}$ were receiving EXE and saline (no statistical differences were noted).

\section{Effect on postprandial glucose and glucagon levels}

Linnebjerg et $\mathrm{a}^{28}$ conducted a randomized, placebo-controlled, open-label, six-way crossover study to assess the effect of EXE $10 \mu \mathrm{g}$ subcutaneous injection timing $(-60,-15$, $0,+30$ and $+60 \mathrm{~min})$ vs placebo $(-15 \mathrm{~min})$ relative to a standardized breakfast meal on postprandial glucose level in patients with type $2 \mathrm{DM}$ during 6 consecutive days. Eighteen patients (mean $[ \pm \mathrm{SD}]$ age, 58 [6.3] years; mean BMI, 29.2 [3.64] $\mathrm{kg} / \mathrm{m}^{2}$; mean $\mathrm{HbA}_{1 \mathrm{c}}, 6.8 \%$ [0.6\%] and fasting plasma glucose, $8.6[1.4] \mathrm{mmol} / \mathrm{L}$ ) receiving oral glucose lowering agents were enrolled in the study. Compared to placebo, there was an overall reduction in postprandial glucose $\mathrm{AUC}_{0-6 \mathrm{~h}}$, $\mathrm{C}_{\max }, \mathrm{C}_{\min }$ and insulin excursions in patients that received premeal EXE at $-60,-15$, and 0 min (Table 2). The lowest glucose concentrations were measured $150 \mathrm{~min}$ after the meal ( $4.4 \mathrm{mmol} / \mathrm{L})$. Inversely, high peak plasma glucose excursions were observed in patients that received EXE postmeal $(+30$ and +60$)$, which were only $21 \%$ and $11 \%$ lower than placebo, respectively (Table 2 ).

In a study conducted by Cervera et $\mathrm{al}^{29}$ the effects of intravenous (IV) EXE on insulin secretion, glucagon suppression, postprandial hyperglycemia and gastric emptying (using acetaminophen $1000 \mathrm{mg}$ dose) were evaluated in 12 patients with type 2 DM taking oral glucose lowering agents and eating a standardized meal (mean [ $\pm \mathrm{SD}$ ] age, 44 [2] years; mean BMI, $34.1[4] \mathrm{kg} / \mathrm{m}^{2}$; mean $\mathrm{HbA}_{1 \mathrm{c}}, 7.5 \%$ [1.5\%] and duration of diabetes, 6.6 [3.5] years). The patients participated in a 3-phase, 6-hour mixed-meal tolerance test conducted 2 to 4 weeks apart: phase 1) intravenous saline infusion during the meal (control); phase 2) IV EXE (0.05 $\mu \mathrm{g} / \mathrm{min})$ started $15 \mathrm{~min}$ before the meal and decreased to $0.025 \mu \mathrm{g} / \mathrm{min} 45 \mathrm{~min}$ after the meal ingestion and phase 3) IV EXE + IV glucagon administered at a rate estimated to match the plasma glucagon level during the saline control phase (phase 1). There was an overall statistically significant reduction in fasting plasma glucose, plasma insulin, C-peptide and glucagon secretion the IV EXE phase compared to the control phase (Table 3). Additionally, the total rate of plasma glucose appearance after the ingestion of the standardized meal over the 360-min period was significantly attenuated in the IV EXE $(212 \pm 6 \mathrm{mg} / \mathrm{min})$ and significantly reduced in the IV EXE + IV glucagon phase $(271 \pm 13 \mathrm{mg} / \mathrm{min})$ compared with control (379 $\pm 30 \mathrm{mg} / \mathrm{min}), P<0.05$. Endogenous glucose remained unchanged during the control phase, however, it was significantly reduced by $40 \%$ in the IV EXE phase and by $20 \%$ in the IV EXE + glucagon phase, $P<0.01$. Lastly, in the IV EXE phase, there was a $58 \%$ significant reduction in mean acetaminophen plasma concentration when compared with the control phase $(840 \pm 135$ vs $1995 \pm 270 \mu \mathrm{g} / \mathrm{mL}, P<0.001)$. 
Table 2 Postprandial glucose excursions in patients with type 2 diabetes mellitus treated with exenatide at various time points relative to a standardized meal ${ }^{28}$

\begin{tabular}{|c|c|c|c|c|c|c|}
\hline & \multirow{2}{*}{$\begin{array}{l}\text { Placebo } \\
-15 \mathrm{~min}\end{array}$} & \multicolumn{5}{|c|}{ Exenatide $10 \mu \mathrm{g}$} \\
\hline & & $-60 \mathrm{~min}$ & $-15 \mathrm{~min}$ & $0 \mathrm{~min}$ & $+30 \mathrm{~min}$ & $+60 \mathrm{~min}$ \\
\hline Postprandial incremental plasma glucose & 311 & -426 & -402 & -418 & -275 & -299 \\
\hline $\mathrm{AUC}_{0-6 \mathrm{~h}}(\mathrm{mmol} / \mathrm{L} \cdot \mathrm{min})^{\dagger}$ & $(124,499)$ & $(-618,-234)$ & $(-590,-215)$ & $(-610,-227)$ & $(-463,-87)$ & $(-486,-111)$ \\
\hline Incremental plasma glucose & 5.81 & 1.41 & 1.54 & 1.88 & 4.57 & 5.19 \\
\hline $\mathrm{C}_{0-6 \mathrm{~h} \max }(\mathrm{mmol} / \mathrm{L})^{*}$ & $(5.06,6.56)$ & $(0.63,2.18)$ & $(0.79,2.30)$ & $(1.10,2.66)$ & $(3.82,5.33)$ & $(4.43,5.94)$ \\
\hline Incremental plasma glucose & -2.33 & -3.22 & -3.51 & -3.82 & -4.06 & -4.35 \\
\hline $\mathrm{C}_{0-6 \mathrm{~h} \min }(\mathrm{mmol} / \mathrm{L})^{\dagger}$ & $(-2.73,-1.93)$ & $(-3.63,-2,8 I)$ & $(-3.91,-3.10)$ & $(-4.23,-3,40)$ & $(-4.47,-3.66)$ & $(-4.75,-3.95)$ \\
\hline Incremental plasma Insulin** & 439.3 & 217 & 263.4 & 268.4 & 529.3 & 526.0 \\
\hline $\mathrm{C}_{0-6 \mathrm{~h} \max }(\mathrm{pmol} / \mathrm{L})$ & $(344.2,560.7)$ & $(169.1,278.4)$ & $(206.4,336.21)$ & $(209.2,344.32)$ & $(4 \mid 4.7,675.53)$ & $(4 \mid 2.2,671.07)$ \\
\hline
\end{tabular}

Note: Data are estimates $(95 \% \mathrm{Cl})$.

t $P<0.05$ vs placebo; $* P<0.05$ vs placebo not including plasma glucose $C_{\max }$ for exenatide $10 \mu \mathrm{g}$ at +60 min; $* * P<0.05$ vs placebo not including plasma insulin $C_{\max }$ for exenatide $10 \mu \mathrm{g}$ at $+30 \mathrm{~min}$ and $+60 \mathrm{~min}$.

Abbreviation: AUC, area under the concentration time curve.

Kolterman et $\mathrm{a}^{30}$ conducted 2 simultaneous studies (A and B) to evaluate the effects of EXE on postprandial glucose levels after using EXE $(0.1 \mu \mathrm{g} / \mathrm{kg})$ SC BID for 5 days (study A) and on glucose levels after an overnight fast using 3 different doses of EXE SC 3 times per day $(0.05 \mu \mathrm{g} / \mathrm{kg}$, $0.1 \mu \mathrm{g} / \mathrm{kg}$ and $0.2 \mu \mathrm{g} / \mathrm{kg}$, study B) in patients with type 2 DM.

Study A was a single blind, placebo-controlled, two-period crossover study with 24 patients with type 2 DM assigned to 4 groups: 1) diet management alone; 2) oral anti-diabetic agent (OAA) $+\mathrm{HbA}_{1 \mathrm{c}}<8 \%$ ); 3) $\mathrm{OAA}+\mathrm{HbA}_{1 \mathrm{c}} \geq 8 \%$ to $12 \%$; 4) insulin $\pm \mathrm{OAA}$ and $\mathrm{HbA}_{1 \mathrm{c}} \leq 12 \%$ (mean $[ \pm \mathrm{SD}]$ age, $55.8[2.1]$ years; mean BMI, 28.8 [0.8] kg/m²; mean weight, 82.9 [3.3] kg). Each dose of EXE was injected subcutaneously before breakfast and dinner. Postprandial glucose was significantly reduced during the 300 min postadministration of EXE (Table 4). Postprandial insulin elevations were reduced significantly in the patients that received EXE on day 5 compared with placebo ( $35 \%$ reduction, $P=0.0011$ ). Data for postprandial plasma insulin concentrations for the placebo or EXE group on day 1 were not provided. Compared to placebo, postprandial glucagon concentrations in patients receiving EXE were significantly lower and relatively unchanged from baseline concentrations $(P=0.0123)$ (Table 4).

Study B was a double blind, placebo-controlled, 4-period crossover study with 13 patients (mean $[ \pm \mathrm{SD}]$ age, 49.0 [2.0] years; mean BMI, 32.8 [1.6] kg/m²; mean weight, $90.6[5.1] \mathrm{kg}$ ) assigned received a single dose of EXE $(0.05 \mu \mathrm{g} / \mathrm{kg}, 0.1 \mu \mathrm{g} / \mathrm{kg}, 0.2 \mu \mathrm{g} / \mathrm{kg})$ and placebo on days 1, 3, 5 and 7 (1-day wash-out period between treatments). Besides EXE treatment, patients were treated

Table 3 Effects of intravenous exenatide on glucose homeostasis and regulatory markers in patients with type 2 diabetes mellitus ${ }^{29}$

\begin{tabular}{|c|c|c|c|}
\hline & $\begin{array}{l}\text { Control } \\
\text { (Phase I) }\end{array}$ & $\begin{array}{l}\text { IV EXE } \\
\text { (Phase 2) }\end{array}$ & $\begin{array}{l}\text { IV EXE + IV glucagon } \\
\text { (Phase 3) }\end{array}$ \\
\hline $\begin{array}{l}\text { Postprandial plasma glucose } \\
\text { AUC }_{0-360 \text { min }}(\mathrm{mg} / \mathrm{dL})^{\dagger}\end{array}$ & $196(9)$ & $127(8)$ & $152(7)$ \\
\hline $\begin{array}{l}\text { Postprandial plasma insulin } \\
\text { AUC }_{0-360 \text { min }}(\mathrm{pmol} / \mathrm{L})^{\dagger}\end{array}$ & $99(12)$ & $179(20)$ & $190(17)$ \\
\hline $\begin{array}{l}\text { Postprandial plasma C-peptide } \\
\text { AUC }_{0-360 \min }(\mathrm{pg} / \mathrm{mL})^{\dagger}\end{array}$ & $7.4(0.8)$ & $12.4(0.9)$ & $16.9(0.8)$ \\
\hline $\begin{array}{l}\text { Postprandial plasma glucagon } \\
\text { AUC }_{0-360 \text { min }}(\mathrm{pg} / \mathrm{mL})^{*}\end{array}$ & $79(6)$ & $67(7)$ & $74(4)$ \\
\hline $\begin{array}{l}\text { Rate of endogenous glucose } \mathrm{mg} / \mathrm{min}^{\dagger * *} \\
A \cup C_{0-360 \min }(\mathrm{mg} / \mathrm{min})\end{array}$ & 249 (19) & $142(12)$ & $209(12)$ \\
\hline
\end{tabular}

Note: Data are mean $( \pm S D)$.

${ }^{\dagger} P<0.05$, IV EXE and IV EXE + IV glucagon vs control; *P $<0.05$, IV EXE vs control; **P $<0.05$, IV EXE vs IV EXE + IV glucagon.

Abbreviations: AUC, area under the concentration time curve; EXE, exenatide. 
Table 4 Glucose, insulin and glucagon concentrations following treatment with exenatide in a selected group of patients with type 2 diabetes mellitus ${ }^{30}$

\begin{tabular}{|c|c|c|c|c|}
\hline & \multicolumn{4}{|c|}{ Study A (exenatide 0.1 mg/kg SC BID) } \\
\hline & \multicolumn{2}{|l|}{ Placebo* } & \multicolumn{2}{|c|}{ Exenatide $0.1 \mu \mathrm{g} / \mathrm{kg}$} \\
\hline & Day I & Day 5 & Day I* & Day 5 \\
\hline $\begin{array}{l}\text { Fasting glucose }(\mathrm{mg} / \mathrm{dL})^{\dagger} \\
\text { before meal }\end{array}$ & $174.6^{*}$ & $170.3(9.1)$ & 176.4 & $159.5(10)$ \\
\hline $\begin{array}{l}\text { Postprandial glucose }{ }^{\dagger} \\
\text { AUC }_{120 \text { min }}(\mathrm{mg} / \mathrm{dL} \cdot \mathrm{min})\end{array}$ & $270 *$ & $289(17)$ & 132.2 & $140 *$ \\
\hline $\begin{array}{l}\text { Postprandial glucose } \mathrm{e}^{\dagger} \\
\mathrm{AUC}_{300 \mathrm{~min}}(\mathrm{mg} / \mathrm{dL} \cdot \mathrm{min})\end{array}$ & $180 *$ & $175.5(14.9)$ & 136.8 & $177.8(14.8)$ \\
\hline $\begin{array}{l}\text { Postprandial plasma }{ }^{\dagger} \\
\text { insulin } A \cup C_{120 \text { min }}(\mu \mathrm{g} \mathrm{U} / \mathrm{mL} \cdot \mathrm{min})\end{array}$ & - & $86.3(28)$ & - & $35.9 *$ \\
\hline Glucagon $(\mathrm{pg} / \mathrm{mL})^{\dagger}$ & - & I $22.7(\mid 8.1)$ & - & $98.9(7.2)$ \\
\hline \multicolumn{5}{|l|}{180 min after meal } \\
\hline & \multicolumn{4}{|c|}{ Study B (multiple doses of exenatide) } \\
\hline & Placebo & $0.05 \mu \mathrm{g} / \mathrm{kg}$ & $0.1 \mu \mathrm{g} / \mathrm{kg}$ & $0.2 \mu g / \mathrm{kg}$ \\
\hline $\begin{array}{l}\text { Fasting glucose }(\mathrm{mg} / \mathrm{dL})^{\dagger} \\
\mathrm{AUC}_{3 \mathrm{hr}}(\mathrm{mg} / \mathrm{dL} \cdot \mathrm{min})\end{array}$ & $195(13.2)$ & I $37.6(9.4)$ & $120.6(8.6)$ & $108.9(6.7)$ \\
\hline $\begin{array}{l}\text { Fasting serum insulin }{ }^{\dagger} \\
C_{\max }(\mu g U / m L)\end{array}$ & $0.9(1.3)$ & $8.8(1.5)$ & $20.0(2.9)$ & $25.6(4.5)$ \\
\hline
\end{tabular}

Note: Data are means (SEM).

${ }^{\dagger} P<0.05$ vs placebo; $*$ Data estimated from figures of ${ }^{30} ;-$ data not provided.

Abbreviation: AUC, area under the concentration time curve.

with diet alone, metformin alone, a thiazolidinedione alone, or a combination of metformin + thiazolidinedione. Patients ingested acetaminophen $(20 \mathrm{mg} / \mathrm{kg})$ at the time of consuming the standardized meal to assess gastric emptying. Compared to placebo: 1) fasting plasma glucose levels were reduced during the 8 hour period of observation (Table 4, $P<0.0001$ ); 2) fasting serum insulin concentrations increased in a dose-depend manner during the first 3 hours postadministration of EXE (Table 4, $P<0.0001$ ); 3) fasting plasma glucagon concentrations were suppressed although it did not reach statistical significance and 4) rate of acetaminophen plasma concentration exposure was reduced by EXE $0.1 \mu \mathrm{g} / \mathrm{kg}$ compared with placebo significantly $\left(\mathrm{AUC}_{180 \text { min }}\right.$, mean $[ \pm \mathrm{SD}] ; 25.8[3.0] \mu \mathrm{mol} / \mathrm{L}$ vs $82.8[5] \mu \mathrm{mol} / \mathrm{L}$, respectively).

\section{Effect on gastric emptying and food intake} Linnebjerg et $\mathrm{a}^{31}$ evaluated the effects of EXE on gastric emptying and appetite perception in patients with type $2 \mathrm{DM}(\mathrm{N}=17)$ in a randomized, single blind, 3-period crossover study (mean [ $\pm \mathrm{SD}]$ age, 57 [10.1] years; mean BMI, 29.2 [3.6] kg/m²; mean $\mathrm{HbA}_{1 \mathrm{c}}, 8.5 \%$ [1.1\%]; duration of diabetes, 6.7 [4.5] years and fasting serum glucose, 9.7 [3.5] $\mathrm{mmol} / \mathrm{L}$ ). Patients received $15 \mathrm{~min}$ prior to breakfast or dinner $5 \mu \mathrm{g}$ of EXE SC BID, EXE $10 \mu \mathrm{g}$ SC BID or placebo for 3 periods of 5 days each. Fifteen minutes after the morning dose on day 5 , patients were instructed to eat a standardized solid and liquid meal within 10 min of the administration of either placebo or EXE. Gastric empting was assessed by scintigraphy and appetite suppression with a visual analog scale (VAS). Compared with placebo, EXE significantly slowed gastric emptying $\left(\mathrm{T}_{50}\right)$ for solid and liquid meals ( solid $\mathrm{T}_{50}, 90 \%$ confidence interval [CI]; placebo, 60 [50-70] min; EXE $5 \mu \mathrm{g}, 111$ [94-132] min; EXE $10 \mu \mathrm{g}, 169$ [143-201] min; liquid $\mathrm{T}_{50}$; placebo, 34 [25-46] min; EXE $5 \mu \mathrm{g}, 87$ [65-117] min; EXE $10 \mu \mathrm{g}, 114$ [85-154] min) $P<0.01$, respectively. EXE reduced postprandial glucose compared with placebo (mean $\mathrm{AUC}_{0-6 \text { hours }}$ [coefficient variation, $\mathrm{CV}$ ] placebo, 60 [29.2] $\mathrm{mmol} * \mathrm{~h} / \mathrm{mL} ; 5 \mu \mathrm{g}, 45.4$ [30.8] $\mathrm{mmol} * \mathrm{~h} / \mathrm{mL}$; $10 \mu \mathrm{g}, 41.4[24.5] \mathrm{mmol} * \mathrm{~h} / \mathrm{mL}, P<0.01)$. EXE reduced postprandial $\mathrm{C}_{\text {max }}$ (mean $\mathrm{C}_{\max }$ [coefficient variation, $\mathrm{CV}$ ] placebo, 13.9 [22.2] mmol/mL; $5 \mu \mathrm{g}, 10.4$ [28.8] mmol/mL; $10 \mu \mathrm{g}, 9.62[19.6] \mathrm{mmol} / \mathrm{mL}, P<0.01)$. Patients who received EXE $5 \mu \mathrm{g}$ felt they could eat less (VAS question \#4, How full do you feel?) 3 to 6 hours after eating the standardized meals compared with placebo (least squares [LS] mean difference $[95 \% \mathrm{CI}] ;-1.23[-2.31,-0.15], P=0.03)$. 
Although a similar perception was found in patients taking EXE $10 \mu \mathrm{g}$ compared with placebo, this difference did not reach statistical significance (LS mean difference [95\% CI]; $-1.01[-2.11,-0.09], P=0.07)$.

Meier $^{32}$ et al evaluated the effects of EXE on insulin secretion, postprandial glucose and gastric emptying in patients with type $2 \mathrm{DM}(\mathrm{N}=12)$ receiving 3 different infusion rates of $\operatorname{EXE}(0.4,0.8$ and $1.2 \mathrm{pmol} / \mathrm{kg} \cdot \mathrm{min})$ or placebo in a fasting state and after a solid standardized meal (mean [ $\pm \mathrm{SD}$ ] age, 57 [9] years; mean BMI, 30.2 [5] kg/m²; mean $\mathrm{HbA}_{1 \mathrm{c}}, 6.8 \%$ [1.3\%]; duration of diabetes, 4 [1] years and waist to hip ratio, 0.95 [0.11]). Under fasting conditions the following data were extrapolated from figures, compared to placebo: 1) fasting glucose concentrations were significantly lowered during the administration of all the EXE infusions (360 min post-treatment administration; $150 \mathrm{mg} / \mathrm{dL}$ [placebo] vs $100 \mathrm{mg} / \mathrm{dL}$ [EXE infusions], $P<0.001$ ); 2) insulin and $\mathrm{C}$-peptide concentrations increased significantly (120 min post-treatment administration; insulin, $10 \mathrm{mU} / \mathrm{L}$ [placebo] vs $40 \mathrm{mU} / \mathrm{L}$ [EXE $1.2 \mathrm{pmol} /$ $\mathrm{kg} * \min$ ], $P<0.001$ and C-peptide, $2 \mathrm{ng} / \mathrm{mL}$ [placebo] vs $7 \mathrm{ng} / \mathrm{mL}$ [EXE $1.2 \mathrm{pmol} / \mathrm{kg} * \mathrm{~min}]$ ); and 3) glucagon concentrations were not significantly different between the placebo group and EXE groups $(P=0.89)$. After the standardized meal test, the EXE $0.8 \mathrm{pmol} / \mathrm{kg} \cdot \mathrm{min}$ and $1.2 \mathrm{pmol} / \mathrm{kg} * \mathrm{~min}$ groups exhibited a significant reduction $(\mathrm{p}=0.001)$ in glucose concentration compared with placebo as early as $60 \mathrm{~min}$ postingestion $\left(\mathrm{AUC}_{120 \mathrm{~min}}\right.$, $100 \mathrm{mg} / \mathrm{dL}$ for both EXE 0.8 and $1.2 \mathrm{pmol} / \mathrm{kg} \cdot \mathrm{min}$ groups vs $250 \mathrm{mg} / \mathrm{dL}$ placebo, respectively). Placebo postprandial insulin concentrations from 60 to $300 \mathrm{~min}$ were significantly higher $(P=0.0031)$ than the concentrations measured after all dosages of EXE, 0.4, 0.8, and $1.2 \mathrm{pmol} / \mathrm{kg} \cdot \mathrm{min}, 4000 \mathrm{mU} / \mathrm{L} \cdot \min \mathrm{vs} 2500,2000$ and $1000 \mathrm{mU} / \mathrm{L}$, respectively. C-peptide secretion from 60 to $300 \mathrm{~min}$ was the highest in the placebo group compared with the EXE $1.2 \mathrm{pmol} / \mathrm{kg} \cdot \mathrm{min}$ group $(P=0.0074,400 \mathrm{ng} / \mathrm{mL} \cdot \mathrm{min}$ vs $150 \mathrm{ng} / \mathrm{mL} \cdot \mathrm{min}$, respectively). Glucagon secretion was suppressed significantly in the EXE groups compared with placebo $(P<0.001)$. At $240 \mathrm{~min}$ postmeal ingestion, gastric emptying was significantly reduced $(P<0.001)$ and the initial gastric contents remained in the stomach in a dose dependent manner in the EXE groups $(0.4,0.8$ and $1.2 \mathrm{pmol} / \mathrm{kg} \cdot \mathrm{min}$ ) compared with placebo; 39\% (6\%), 56\% (9\%), 74\% (9\%) vs 26\% (3\%), respectively.

Toft-Nielsen et $\mathrm{a}^{33}$ conducted a randomized, single blind study to assess the effects of EXE SC injection (1.2 and $2.4 \mathrm{pmol} / \mathrm{kg} \cdot \mathrm{min})$ on appetite/satiety and insulin, glucose and glucagon concentrations in 10 patients with type $2 \mathrm{DM}$ for 48 hours. Four patients received a dose of EXE $1.2 \mathrm{pmol} / \mathrm{kg} \cdot \mathrm{min}$ SC once daily for 48 hours (mean [ $\pm \mathrm{SD}$ ] age, 49.3 [2.7] years; mean BMI, 34.3 [3.4] kg/m²; mean $\mathrm{HbA}_{1 \mathrm{c}}, 9.3 \%$ [1.6\%]; duration of diabetes, 4.0 [2.1] years) and 6 patients received a dose of $2.4 \mathrm{pmol} / \mathrm{kg} \cdot \mathrm{min}$ SC BID for 48 hours (mean [ \pm SD] age, 59 [ 2.8] years; mean BMI, 34.0 [1.4] kg/m²; mean $\mathrm{HbA}_{1 \mathrm{c}}, 8.8 \%$ [0.3\%]; duration of diabetes, 4.1 [2.1] years). All patients were instructed to follow a detailed diabetes diet, to use a portable infusion pump for treatment delivery and to rate sensations of hunger, satiety, fullness, prospective food consumption, nausea and overall well-being on a VAS of 100 points. Twelve hours after the patients received $\mathrm{EXE}$ dose $4 \mathrm{pmol} / \mathrm{kg} * \mathrm{~min} \mathrm{SC}$, satiety rates significantly increased compared with control (50 vs 40) and prospective food consumption significantly decreased in the EXE group compared with control (40 vs 60), $P<0.05$ respectively. Similarly, at 18 hours after EXE $4 \mathrm{pmol} / \mathrm{kg} \cdot \mathrm{min} \mathrm{SC}$, satiety rates significantly increased compared with control (100 vs 80 ) and prospective food consumption ( 0 vs 20 ) and hunger ( 0 vs 10$)$ significantly decreased, $P<0.05$ respectively. Additionally, on day 2 , 24-hour mean glucose decreased from $15.4 \pm 1.0$ (control) to $13.0 \pm 1.0 \mathrm{mmol} / \mathrm{L}(\mathrm{EXE}, P=0.0009)$ and fasting glucose decreased from $14.1 \pm 0.9$ (control) to $12.2 \pm 0.7 \mathrm{mmol} / \mathrm{L}$ (EXE, $P=0.009)$. Mean insulin levels increased from $189 \pm 40 \mathrm{pmol} / \mathrm{L}$ to $224 \pm 48 \mathrm{pmol} / \mathrm{L}(P=0.03)$ and mean $\mathrm{C}$-peptide levels increased from $2122 \pm 312 \mathrm{pmol} / \mathrm{L}$ to $2336 \pm 285 \mathrm{pmol} / \mathrm{L}(\mathrm{EXE}, P=0.0003)$.

\section{Clinical efficacy and safety}

\section{Twice daily monotherapy}

Moretto et al ${ }^{34}$ conducted a 24-week, randomized, double-blind, placebo-controlled, parallel-group study to determine the efficacy and tolerability of EXE $5 \mu \mathrm{g}$ or $10 \mu \mathrm{g}$ in treatment-naïve patients with type $2 \mathrm{DM}$. Patients were excluded if they had blood pressures $\geq 160 / 110 \mathrm{mmHg}$ or received medications for weight loss within 12 weeks of screening. Patients received SC injections of PCB BID for 2 weeks and were then randomized to 1 of 3 groups: PCB $(\mathrm{N}=77,55 \%$ males, mean $\pm \mathrm{SD}$ age $53 \pm 9$ years, $66 \%$ White and 27\% Asian,) EXE $5 \mu \mathrm{g}$ BID ( $\mathrm{N}=77,52 \%$ males, $54 \pm 10$ years of age, 65\% White and 29\% Asian), EXE $10 \mu \mathrm{g}$ BID $(\mathrm{N}=78,62 \%$ males, $55 \pm 10$ years of age, $72 \%$ White and 23\% Asian); those in the EXE $10 \mu \mathrm{g}$ BID group were initiated on $5 \mu \mathrm{g}$ BID for 4 weeks followed by $10 \mu \mathrm{g}$ BID for 20 weeks. Patients self-administered 
treatment SC in the upper arm, thigh, or abdomen $15 \mathrm{~min}$ before morning and evening meals. The primary endpoint was change from baseline in $\mathrm{HbA}_{1 \mathrm{c}}$ at week 24 or lastobservation-carried-forward.

The baseline mean $\pm \mathrm{SD} \mathrm{HbA}_{1 \mathrm{c}}$ for those in the PCB, EXE $5 \mu \mathrm{g}$ and EXE $10 \mu \mathrm{g}$ groups were as follows: $7.8 \% \pm 0.9 \%, 7.9 \% \pm 1.0 \%$, and $7.8 \% \pm 1.0 \%$; at 24 weeks, the mean change in $\mathrm{HbA}_{1 \mathrm{c}}$ was $-0.2 \% \pm 0.1 \%$, $-0.7 \% \pm 0.1 \%$, and $-0.9 \% \pm 0.1 \%$, respectively $(P<0.001$ EXE $10 \mu \mathrm{g}$ vs $\mathrm{PCB}$ and $\mathrm{P}=0.003 \mathrm{EXE} 5 \mu \mathrm{g}$ vs $\mathrm{PCB})$. A linear dose effect indicated more improvement in $\mathrm{HbA}_{1 \mathrm{c}}$ with the higher dose of $\operatorname{EXE}(P=0.024)$. At baseline, the fasting serum glucose (FSG) was 154 to $166 \mathrm{mg} / \mathrm{dL}$ for all groups; at 24 weeks, the mean change in FSG was $-5.2 \pm 4.0 \mathrm{mg} / \mathrm{dL}$, $-17.5 \pm 4.0 \mathrm{mg} / \mathrm{dL}$, and $-18.7 \pm 4.0 \mathrm{mg} / \mathrm{dL}$, respectively $(P=0.016$ EXE $10 \mu \mathrm{g}$ vs $\mathrm{PCB}$ and $\mathrm{P}=0.029 \mathrm{EXE} 5 \mu \mathrm{g}$ vs $\mathrm{PCB})$. At baseline, the weight was 85 to $86 \mathrm{~kg}$ for all groups; at 24 weeks, the mean change in weight was $-1.4 \pm 0.3 \mathrm{~kg},-2.8 \pm 0.3 \mathrm{~kg}$, and $-3.1 \pm 0.3 \mathrm{~kg}$, respectively $(P<0.001 \mathrm{EXE} 10 \mu \mathrm{g}$ vs $\mathrm{PCB}$ and $\mathrm{P}=0.004 \mathrm{EXE}$ $5 \mu \mathrm{g}$ vs PCB). Significant changes in weight occurred at weeks $8,12,16$, and 24 in patients randomized to the EXE $10 \mu \mathrm{g}$ vs PCB $(P \leq 0.007)$ and at weeks 16 and 24 for those in the EXE $5 \mu \mathrm{g}$ vs PCB groups $(P \leq 0.027)$, respectively. Pancreatic $\beta$-cell function (determined by HOMA-B) increased by $6 \%, 32 \%$ and $28 \%$, respectively $(P=0.01$ EXE $10 \mu \mathrm{g}$ vs $\mathrm{PCB}$ and $P=0.002$ EXE $5 \mu \mathrm{g}$ vs $\mathrm{PCB})$. The most common treatment-emergent adverse events reported in $\geq 2 \%$ of patients in the EXE $5 \mu \mathrm{g}$, EXE $10 \mu \mathrm{g}$, and PCB groups were hypoglycemia ( $\mathrm{n}=4, \mathrm{n}=3$ and $\mathrm{n}=1)$, headache $(\mathrm{n}=4, \mathrm{n}=2$, and $\mathrm{n}=3)$, influenza $(\mathrm{n}=3, \mathrm{n}=5$, and $\mathrm{n}=3)$, and nausea $(\mathrm{n}=2, \mathrm{n}=10$, and $\mathrm{n}=0 ; P=0.01$ for combined EXE group vs PCB).

Limitations of this study included short duration of 24 weeks and small sample size as only 66, 68, and 69 patients in the EXE $5 \mu \mathrm{g}$, EXE $10 \mu \mathrm{g}$ and PCB groups completed the study.

\section{Once weekly monotheraphy}

Drucker et $\mathrm{al}^{35}$ conducted a 30 -week, randomized, comparatorcontrolled, open-labeled, non-inferiority study to determine the efficacy and safety of EXE $2 \mu \mathrm{g}$ sustained-release formulation injected SC week ( $\mathrm{N}=148,55 \%$ males, $83 \%$ White, mean \pm SD age $55 \pm 10$ years, mean DM duration $7 \pm 6$ years $)$ vs EXE $10 \mu \mathrm{g}$ SC BID $(\mathrm{N}=147,51 \%$ males, $73 \%$ White, $55 \pm 10$ years of age, $6 \pm 5$ years DM duration). Concomitant DM medications included MET (77\% vs 60\%), SUs (37\% in both groups), or a thiazolidinedione (TZDs)
(15\% vs 17\%), respectively. Patients receiving insulin or any agents that altered GI motility were excluded from the study. The cutoff value used to determine no difference between the treatments was the upper limit of the two-sided 95\% CI for the difference in $\mathrm{HbA}_{1 \mathrm{c}}$ change was $<0.4 \%$.

At baseline, the mean $\pm \mathrm{SD} \mathrm{HbA}_{1 \mathrm{c}}$ and weight for all patients were $8.3 \% \pm 1.0 \%$ and $102 \pm 19 \mathrm{~kg}$, respectively. At week 30, patients randomized to EXE once weekly group vs BID group reported a reduction in $\mathrm{HbA}_{1 \mathrm{c}}$ of $-1.9 \% \pm$ $0.1 \%$ vs $-1.5 \% \pm 0.1 \%$ (mean difference between the groups $-0.33 \% \pm 0.1 \%, 95 \% \mathrm{CI}-0.54$ to -0.12 ), intentionto-treat (ITT) $P=0.0023$. Therefore, EXE once weekly was not inferior to $10 \mu \mathrm{g}$ BID. Overall, $77 \%$ vs $61 \%$ of patients, respectively, reached a target $\mathrm{HbA}_{1 \mathrm{c}} \leq 7 \%(P=0.0039) ; 65 \%$ vs $35 \%$ of patients with a baseline $\mathrm{HbA}_{1 \mathrm{c}} \leq 9 \%$ reached a target $\mathrm{HbA}_{1 \mathrm{c}} \leq 7 \%(P=0.02)$. Mean $\pm \mathrm{SE}$ change in fasting plasma glucose was $-2.3 \pm 0.2 \mathrm{mmol} / \mathrm{L} \mathrm{vs}-1.4 \pm 0.2 \mathrm{mmol} / \mathrm{L}$, $95 \%$ CI -1.3 to -0.52 , ITT $P<0.0001$, respectively. The mean $\pm \mathrm{SE}$ reduction in weight was $-3.7 \pm 0.5 \mathrm{~kg}$ vs $-3.6 \pm$ $0.5 \mathrm{~kg}, 95 \% \mathrm{CI}-1.3$ to 1.1 , ITT $P=0.89$. Fifty-one patients underwent a meal tolerance test at baseline and at 30 weeks. The change from baseline in 2-hour postprandial plasma glucose was $-6.9 \pm 0.5 \mathrm{mmol} / \mathrm{L}$ vs $-5.3 \pm 0.5 \mathrm{mmol} / \mathrm{L}, 95 \%$ CI -0.4 to $-2.9, P=0.0124$, respectively. At baseline, the mean \pm SD glucagon levels were $103 \pm 3.1 \mathrm{ng} / \mathrm{L}$ vs $99.0 \pm$ $3.0 \mathrm{ng} / \mathrm{L}$; at week 30 , the least square mean \pm SE glucagon reductions were $-18.0 \pm 2.9 \mathrm{ng} / \mathrm{L}$ vs $-6.4 \pm 2.9 \mathrm{ng} / \mathrm{L}$, $P<0.05$, respectively.

The most commonly reported AEs reported by $\geq 5 \%$ of those in the EXE once weekly group vs BID group were nausea $(26.4 \%$ vs $34.5 \%)$, vomiting (10.8\% vs $18.6 \%)$, injection site pruritus (17.6\% vs 1.4\%), upper respiratory tract infections ( $8.1 \%$ vs $17.2 \%)$, diarrhea (13.5\% vs $13.1 \%)$, constipation (10.8\% vs 6.2\%), injection-site bruising $(4.7 \%$ vs $10.3 \%)$, and urinary tract infections (10.1\% vs $8.3 \%$ ), respectively. Nine vs 7 patients, respectively, withdrew from the study for various reasons. No major episodes of hypoglycemia were reported, but in 16 patients receiving sulfonylureas, 8 patients in each group complained of minor episodes of hypoglycemia, respectively. No episodes of pancreatitis were reported.

\section{Efficacy with metformin and sulfonylureas}

Three 30-week randomized, triple-blind, placebo-controlled, parallel-group studies were conducted to evaluate the effect of EXE on glycemic control in patients failing maximally effective doses of sulfonylurea monotherapy (SU) ${ }^{36}$ metformin (MET) monotherapy, ${ }^{37}$ or combination therapy (SU + MET). ${ }^{38}$ 
Patients in the study with background SUs only received one of the following: glimepiride $4 \mathrm{mg}$ /day, glipizide $20 \mathrm{mg} /$ day, glipizide XL $10 \mathrm{mg} /$ day, glyburide $10 \mathrm{mg} /$ day, micronized glyburide $6 \mathrm{mg} /$ day, chlorpropamide $350 \mathrm{mg} /$ day, tolazamide $500 \mathrm{mg} /$ day. ${ }^{36}$ Patients in the study with background MET only received $\geq 1500 \mathrm{mg} /$ day. ${ }^{37}$ In the study where patients received combination therapy, all patients received $\mathrm{MET} \geq 1500 \mathrm{mg} /$ day and SUs; to standardize SU use, patients were randomized either to a maximally effective group (MAX group, dosages listed above) or minimally effective group (MIN group, at the following dosages: glimepiride $1 \mathrm{mg} /$ day, glipizide $5 \mathrm{mg}$ /day, glipizide XL $5 \mathrm{mg} /$ day, glyburide $1.25 \mathrm{mg} /$ day, micronized glyburide $0.75 \mathrm{mg} /$ day, chlorpropamide $100 \mathrm{mg} /$ day, tolazamide $100 \mathrm{mg} /$ day, or tolbutamide $250 \mathrm{mg} /$ day). ${ }^{38}$ To address hypoglycemia in patients receiving SU, 50\% reductions in dose or eventual discontinuation (depending on the recurrence of hypoglycemia) in the event of a documented episode or two undocumented or suspected episodes were allowed. ${ }^{36,38}$ Patients self-administered placebo (PCB) SC twice daily for 4 weeks; after that, those randomized to active treatment received another 4 weeks of EXE $5 \mu \mathrm{g}$ SC BID $15 \mathrm{~min}$ before a meal; then, half of these patients maintained their dose of EXE at $5 \mu \mathrm{g}$ SC BID and the other half increased the dose to $10 \mu \mathrm{g}$ SC BID. ${ }^{36-38}$

In two studies, ${ }^{37,38}$ a subset of patients underwent a standardized meal tolerance test at weeks 0,4 , and 30 to determine the effect of EXE on postprandial glucose concentrations. After an overnight fast, patients took their morning dose of MET or MET $+\mathrm{SU}$; then, patients received PCB or EXE injection $15 \mathrm{~min}$ prior to the standardized breakfast (55\% carbohydrate, $15 \%$ protein, $30 \%$ fat based on body weight and activity level). Patients were excluded from the studies if they received thiazolidinediones, meglitinides, $\alpha$-glucosidase inhibitors, insulins, weight-loss agents, and corticosteroids within 3 months of study initiation; patients in the SU monotherapy study could not receive MET and vice versa. Outcome measures included effect on $\mathrm{HbA}_{1 \mathrm{c}}$, tolerability, fasting and postprandial glucose levels (meal test), and body weight.

To determine the long-term ( 82 weeks) efficacy and tolerability of EXE, two uncontrolled, open-labeled studies using patients from the three 30 -week studies ${ }^{36-38}$ were conducted. In the study by Blonde et $\mathrm{al}^{39}$ all patients that received EXE and completed the three 30-week initial studies $(\mathrm{N}=668)$ were allowed to enter the open-label extension phase; 551 patients entered the study (ITT population) and 314 patients were completers. The patients were allowed to continue SUs and MET with dose adjustments made as needed by provider. In the study by Ratner et al ${ }^{40}$ all patients who received MET + EXE and completed the 30 -week initial study $(\mathrm{N}=183)$ were allowed to enter the open-label extension phase; 150 patients entered the study (ITT population) and 92 patients were completers. The patients were allowed to continue MET monotherapy. At the start of the uncontrolled phase for both studies, the patients received EXE $5 \mu \mathrm{g}$ SC BID for 4 weeks followed by $10 \mu \mathrm{g}$ SC BID for the duration of the study. ${ }^{39,40}$

Patient demographics, withdrawals and results for the three 30-week studies ${ }^{36-38}$ and two open-label studies ${ }^{39,40}$ are given in Tables 5 and 6 . In the three 30-week studies, there was a dose-dependent, significant reduction in $\mathrm{HbA}_{1 \mathrm{c}}$ vs $\mathrm{PCB}$ at 30 weeks $(P \leq 0.05)$; reductions began within the first 2 to 5 weeks of treatment. ${ }^{36-38}$ In patients with a baseline $\mathrm{HbA}_{1 \mathrm{c}}<9 \%$ and on background SU monotherapy, the reduction in mean $\pm \mathrm{SE} \mathrm{HbA}_{1 \mathrm{c}}$ was $-0.65 \pm$ $0.12 \%(n=83),-0.39 \pm 0.12 \%(n=79)$, and $0.11 \pm 0.12 \%$ $(\mathrm{n}=77)$ for those in the EXE $10 \mu \mathrm{g}$, EXE $5 \mu \mathrm{g}$, and PCB groups $(P<0.01$ and $P<0.0001$ vs $\mathrm{PCB})$, respectively. In patients with baseline mean $\pm \mathrm{SE} \mathrm{HbA}_{1 \mathrm{c}} \geq 9 \%$, the mean reduction was $-1.22 \pm 0.19 \%(\mathrm{n}=46),-0.58 \pm$ $0.24 \%(\mathrm{n}=46)$, vs $0.13 \pm 0.17 \%(\mathrm{n}=46),(P<0.05$ and $P<0.0001)$, respectively. When patients with a baseline $\mathrm{HbA}_{1 \mathrm{c}}<9 \%$ and received background $\mathrm{SU}+\mathrm{MET}$ therapy, the reduction in mean $\mathrm{HbA}_{1 \mathrm{c}}$ was $-0.5 \%,-0.4 \%$, vs $0.29 \%$, ( $P<0.001$ for both EXE groups vs PCB), respectively; when the baseline $\mathrm{HbA}_{1 \mathrm{c}} \geq 9 \%$, the mean reduction was $-1.35 \%,-0.85 \%$, vs $0 \%,(P<0.001$ for both EXE groups vs PCB), respectively (data extrapolated from figure). The change in $\mathrm{HbA}_{1 \mathrm{c}}$ for those on MAX SUs doses and MIN SUs doses were $-0.9 \pm 0.1 \%,-0.7 \pm 0.1 \%,+0.2 \pm 0.1 \%$ and $-0.6 \pm 0.1 \%,-0.4 \pm 0.1 \%,+0.3 \pm 0.1 \%$, respectively $(P<0.0001$ for both EXE groups vs PCB).

When patients who received EXE from the three studies were combined, $\mathrm{N}=314 / 551$ completed the open-label extension phase (all patients received EXE $10 \mu \mathrm{g}$ SC BID). ${ }^{39}$ The mean \pm SE change in $\mathrm{HbA}_{1 \mathrm{c}}$ from baseline to week 30 during the PCB-controlled studies for these 314 patients was $-0.9 \pm 0.1 \%$; the change from baseline to week 82 was $-1.1 \pm 0.1 \%$ [95\% CI -1.0 to $-1.3 \%]$. The change in $\mathrm{HbA}_{1 \mathrm{c}}$ for those with $\mathrm{HbA}_{1 \mathrm{c}} \geq 9 \%$ and $\mathrm{HbA}_{1 \mathrm{c}}<9 \%$ was $-2.0 \pm 0.2 \%$ and $-0.8 \pm 0.1 \%$, respectively. ${ }^{39}$ In the study where patients received background MET monotherapy and chose to complete the open-label extension phase $(\mathrm{N}=92 / 150)$, the mean $\pm \mathrm{SE}$ change in $\mathrm{HbA}_{1 \mathrm{c}}$ from baseline to week 30 during the PCB-controlled study for these 92 patients was $-1.0 \pm 0.1 \%$; the change from baseline 


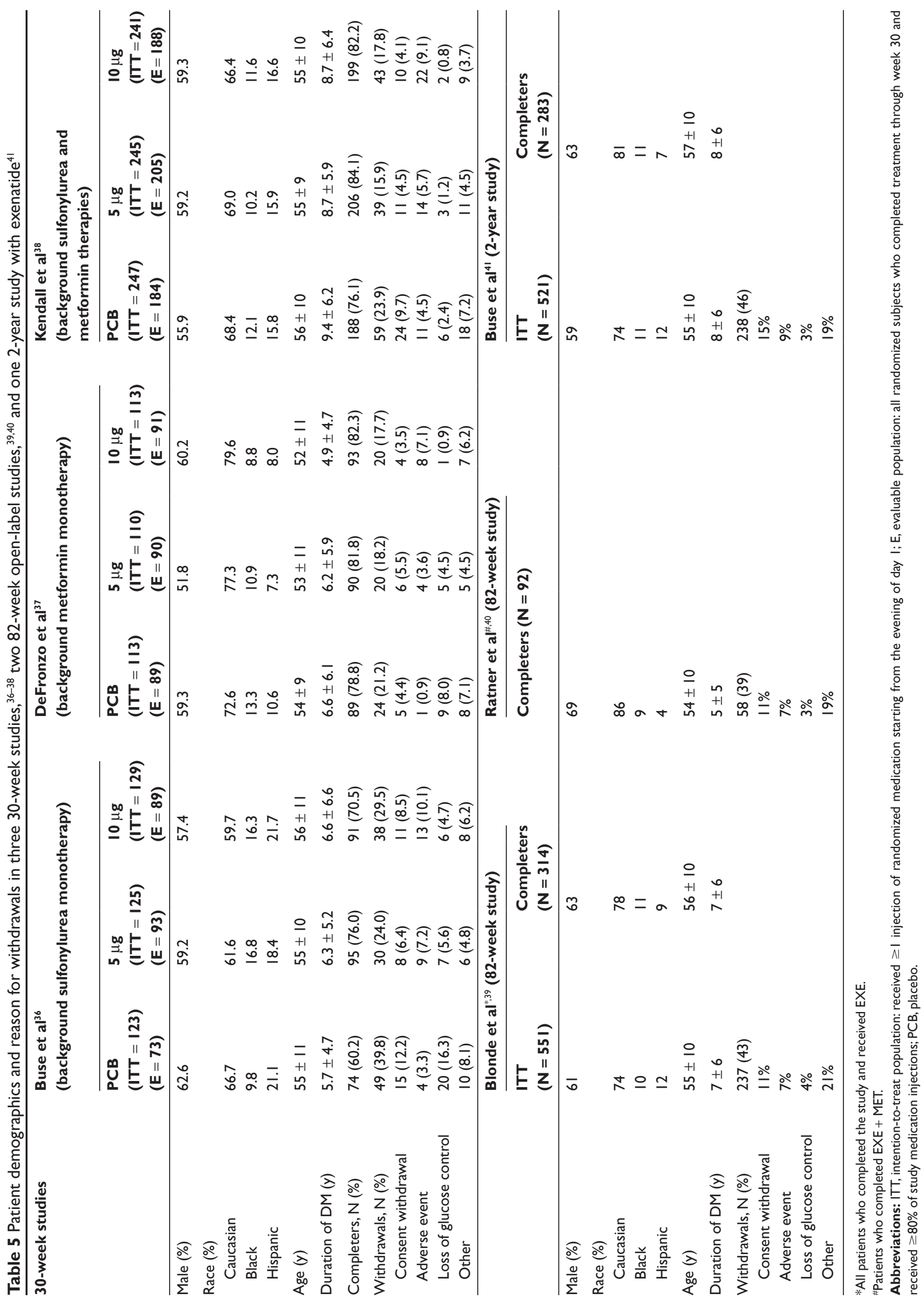




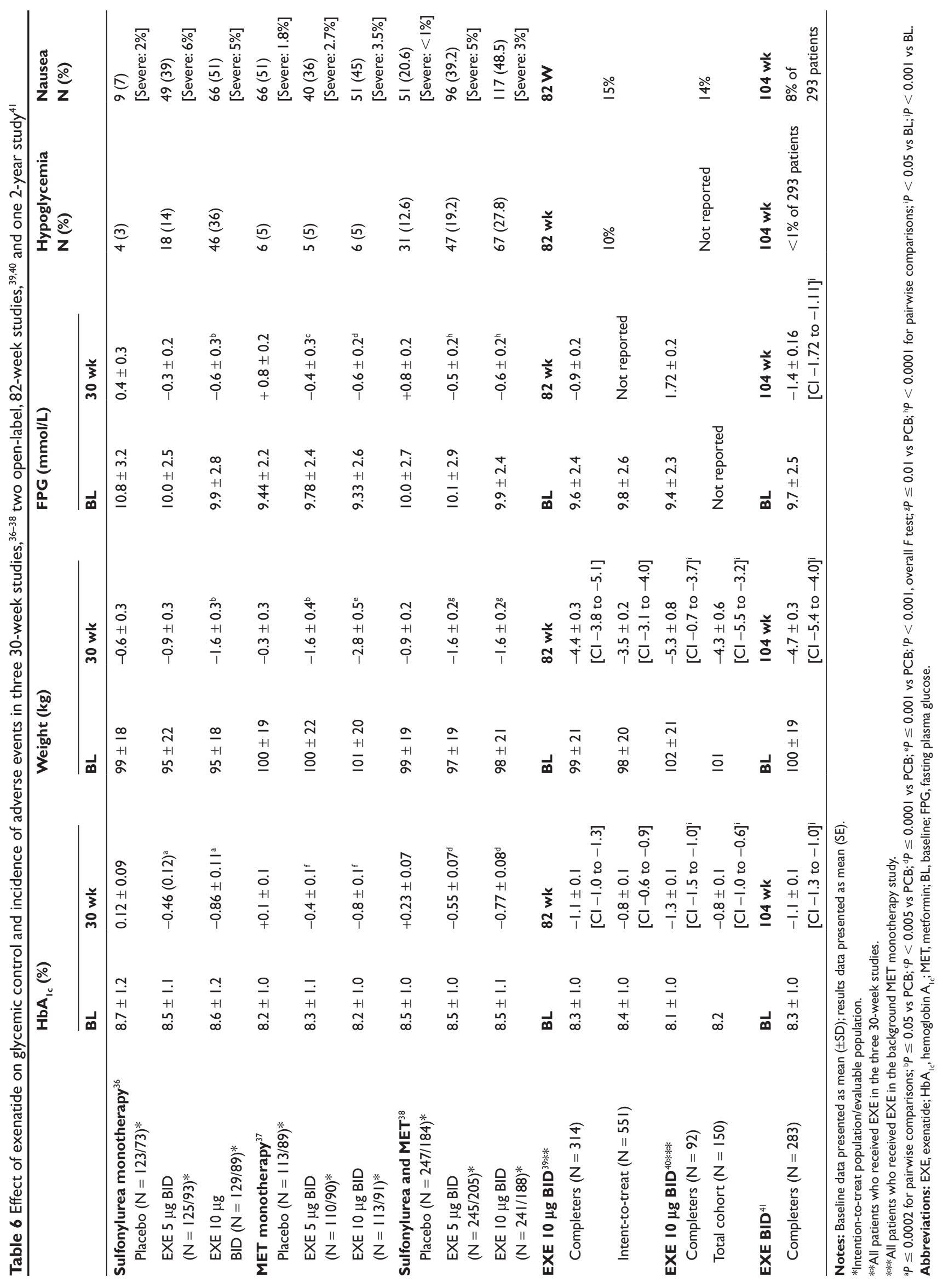


to week 82 was $-1.3 \pm 0.1 \%$ [95\% CI -1.5 to $-1.0 \%$, $P<0.05] .^{40}$

To determine the effect of EXE on postprandial plasma glucose (PPPG), the PPPG geometric mean $\mathrm{AUC}_{15-180 \text { min }}$ values were obtained at baseline (patients received $\mathrm{PCB}$ only) and at 30 weeks (SU + MET vs SU + MET + EXE) ${ }^{38}$ The PPPG geometric mean $\mathrm{AUC}_{15-180 \text { min }}$ for those in the EXE $10 \mu \mathrm{g}(\mathrm{n}=27)$, EXE $5 \mu \mathrm{g}(\mathrm{n}=27)$ vs PCB $(\mathrm{n}=23)$ groups were $2033 \mathrm{mmol} \cdot \mathrm{min} / \mathrm{L}, 2089 \mathrm{mmol} \cdot \mathrm{min} / \mathrm{L}$, vs $2090 \mathrm{mmol} \cdot \mathrm{min} / \mathrm{L}$, respectively; at week 30 , the values were $1539 \mathrm{mmol} \cdot \mathrm{min} / \mathrm{L}, 1584 \mathrm{mmol} \cdot \mathrm{min} / \mathrm{L}$, vs $2087 \mathrm{mmol} \cdot \mathrm{min} / \mathrm{L}$ ( $P=0.0004$ and $P=0.0009$ vs $\mathrm{PCB})$, respectively. ${ }^{38}$ The standardized meal tolerance test was performed in a subset of patients in the MET study, however, the PPPG geometric mean $\mathrm{AUC}_{15-180 \text { min }}$ were not provided. ${ }^{37}$ The authors stated that EXE $10 \mu \mathrm{g}$ and $5 \mu \mathrm{g}$ caused a significant reduction in PPPG vs baseline $(P=0.004$ and $P=0.03)$, respectively. ${ }^{37}$

There were no significant changes to insulin concentrations from baseline when patients received SU + EXE or MET + EXE. ${ }^{36-38}$ One study (SU + EXE) reported a significant reduction in fasting proinsulin concentrations when patients received EXE $10 \mu \mathrm{g}$ vs baseline $(-16 \mathrm{pmol} / \mathrm{L}, 95 \%$ CI -26.1 to -6.0$)$ and vs PCB $(P<0.05) .{ }^{36}$ Body weight was reduced in all groups that received EXE $10 \mu \mathrm{g}$ vs PCB $(P \leq 0.05) ;{ }^{36-38}$ patients who received SU + EXE $5 \mu \mathrm{g}$ did not report a significant reduction in body weight ${ }^{36}$ and those who received MET + EXE $10 \mu \mathrm{g}$ reported the most weight loss. ${ }^{37}$ In the 314 patients who completed the 52-week open-label extension phase (continued background SU and MET plus EXE $10 \mu \mathrm{g}$ SC BID), the mean \pm SE change in body weight from baseline to week 30 of the PCB-controlled studies was $-2.1 \pm 0.2 \mathrm{~kg}$; at week 82 , the change was $-4.4 \pm 0.3 \mathrm{~kg}[95 \% \mathrm{CI}-3.8$ to $-5.1 \mathrm{~kg}] .^{39}$ When patients received MET + EXE, SU + EXE, or MET + SU + EXE during the extension phase, the mean weight reduction was $5.3 \mathrm{~kg}, 3.9 \mathrm{~kg}$, and $4.1 \mathrm{~kg}$, respectively. ${ }^{39}$ In the 92 patients who completed the 52-week open-label extension phase (continued background MET plus EXE $10 \mu \mathrm{g}$ SC BID), the mean \pm SE change in body weight from baseline to week 30 of the PCB-controlled study was $-3.0 \pm 0.6 \mathrm{~kg}$; at week 82 , the change was $-5.3 \pm 0.8 \mathrm{~kg}[95 \% \mathrm{CI}-7.0$ to $-3.7 \mathrm{~kg}, P<0.05] .^{40}$ When baseline body mass index $(\mathrm{BMI}) \geq 30 \mathrm{~kg} / \mathrm{m}^{2}$, the weight reduction was $-6.9 \pm 1.1 \mathrm{~kg}$; the weight loss was less for those with a BMI $<30 \mathrm{~kg} / \mathrm{m}^{2}$ at $-2.3 \pm 0.8 \mathrm{~kg} .{ }^{40}$

In the three 30 -week studies, the most commonly reported adverse events (AEs) in the EXE $10 \mu \mathrm{g}(\mathrm{N}=483)$,
EXE $5 \mu \mathrm{g}(\mathrm{N}=480)$, and PCB $(\mathrm{N}=483)$ groups included hypoglycemia $(\mathrm{N}=119$ or $25 \%, \mathrm{~N}=70$ or $15 \%$, and $\mathrm{N}=41$ or $9 \%$ ) and nausea ( $\mathrm{N}=234$ or $48 \%, \mathrm{~N}=185$ or $39 \%$, and $\mathrm{N}=86$ or $18 \%$ ), respectively. ${ }^{36-38}$ Patients reported that the hypoglycemia and nausea were of mild-to-moderate severity and peaked within the first 2 months of treatment. More patients in the SU-only study and SU + MET study receiving EXE reported hypoglycemia vs those receiving SU alone, SU + MET alone, MET alone, or MET + EXE therapies. ${ }^{36-38}$ In the SU + MET study, ${ }^{38}$ the incidence of hypoglycemia for those on MAX SUs and MIN SUs dosages were and randomized to EXE $10 \mu \mathrm{g}, 5 \mu \mathrm{g}$, and PCB similar at $35 \%, 22 \%, 15 \%$, and $21 \%, 16 \%, 10 \%$, respectively.

Post-hoc analyses revealed no correlations between weight loss and nausea in the three studies. ${ }^{36-38}$ In the background SUs monotherapy study, ${ }^{36}$ the mean \pm SD weight loss for those in the EXE $10 \mu \mathrm{g}$, EXE $5 \mu \mathrm{g}$, and PCB groups but never reported nausea were $-1.4 \pm 3.6 \mathrm{~kg}$ (61 patients), $-0.6 \pm 3.0 \mathrm{~kg}$ (75 patients), and $-0.7 \pm 3.1 \mathrm{~kg}$ (110 patients); respectively; in those who had $\geq 1$ episode of nausea, the weight loss was $-1.7 \pm 3.2 \mathrm{~kg}$ ( 65 patients), $-1.3 \pm 2.9 \mathrm{~kg}$ (48 patients), and $0.6 \pm 4.7 \mathrm{~kg}$ (9 patients), respectively. ${ }^{36}$ In the background SU + MET study, the weight loss for those who never experienced nausea was $-1.1 \pm 0.3 \mathrm{~kg}(10-\mu \mathrm{g}$ group) and $-1.7 \pm 0.2 \mathrm{~kg}$ (5- $\mu \mathrm{g}$ group). Both open-label extension studies reported that there were no correlations with weight loss and nausea $(r=-0.11$ for the $\mathrm{SU}+\mathrm{MET}$ extension study $)^{39}$ and $(r=-0.071$ for the MET extension study). ${ }^{40}$

An interim analysis was performed to evaluate the association among observed changes in glycemic control, weight reduction, and liver injury biomarkers in patients from the above-mentioned 3 studies who completed 2 years of EXE therapy. ${ }^{41}$ The 2-year completer cohort $(\mathrm{N}=283$, demographics in Table 5) was defined as all subjects who had the opportunity to achieve 2 years of EXE exposure, regardless of their treatment arm in the 30-week placebo-controlled studies. At 104 weeks, there was a statistically significant reduction in $\mathrm{HbA}_{1 \mathrm{c}}$, weight, and fasting plasma glucose compared with baseline $(P<0.001$ for all comparisons $)$ (Table 6). In 213 patients with a mean baseline $\mathrm{HbA}_{1 \mathrm{c}}$ $7.8 \%$, the mean \pm SE change was $-0.9 \% \pm 0.1 \%$; in those with a mean $\mathrm{HbA}_{1 \mathrm{c}} 9.7 \%(\mathrm{n}=70)$, the mean $\pm \mathrm{SE}$ change was $-2.0 \% \pm 0.2 \%$. The mean \pm SE change in $\mathrm{HbA}_{1 \mathrm{c}}$ stratified by BMI was similar for patients with a baseline $\mathrm{BMI}<30$, $\geq 30$ but $<40$, and $\geq 40$ at $-1.2 \% \pm 0.1 \%,-1.1 \% \pm 0.1 \%$, and $-1.2 \% \pm 0.2 \%$, respectively. HOMA-B data were collected in 112 patients and significantly increased from baseline 
(mean \pm SE 50\%, $P<0.01$; numerical value extrapolated from figure) with a smaller improvement in HOMA-S ( $8.3 \%$ change in median HOMA-S; $P<0.01$ vs baseline). There was a reduction in mean ALT $(-5.3 \mathrm{IU} / \mathrm{L} ; 95 \% \mathrm{CI}-7.1$ to $-3.5, P<0.05)$ and $\mathrm{AST}(-2.0 \mathrm{IU} / \mathrm{L} ; 95 \% \mathrm{CI}-3.3$ to $-0.8, P<0.05)$ values at week 104 . Those with elevated ALT and AST at baseline showed a reduction at week 104: $-11 \mathrm{IU} / \mathrm{L} ; 95 \% \mathrm{CI}-14$ to $-8, P<0.001$ and $-5 \mathrm{IU} / \mathrm{L}$, $95 \% \mathrm{CI}-7$ to $-3, \mathrm{P}<0.001$, respectively. Baseline mean SBP and DBP were 130.2 $\pm 0.8 \mathrm{mmHg}$ and $78.8 \pm 0.5 \mathrm{mmHg}$; at week 104, a reduction in $\operatorname{SBP}(-2.6 \pm 0.9 \mathrm{mmHg}$ (95\% CI -4.3 to $-0.9, P=0.003)$ and $\operatorname{DBP}(-1.9 \pm 0.5 \mathrm{mmHg}$ (95\% CI -3.0 to $-0.9, \mathrm{P}<0.001)$ was observed. Fortyfive of 238 patients withdrew due to adverse events; mild to moderate nausea was the most frequently reported $\mathrm{AE}$, independent of age, with 3\% withdrawing over the 2 years because of nausea (Table 6).

Elkind-Hirsch et $\mathrm{al}^{42}$ conducted an open-label, prospective, randomized, outpatient clinical study over 24 weeks to determine the change in menstrual frequency in patients with PCOS (polycystic ovary syndrome). Patients were randomized to MET $1000 \mathrm{mg} \mathrm{BID}(\mathrm{N}=20$, mean $\pm \mathrm{SEM}$ age $27.7 \pm 1.3$ years $)$, EXE $10 \mu \mathrm{g} \operatorname{BID}(\mathrm{N}=20$, mean \pm SEM age $28.2 \pm 1.1$ years $)$, or MET $+\operatorname{EXE}(N=20$, mean \pm SEM age $32.1 \pm 0.7$ years) and underwent clinical, metabolic, and laboratory evaluations before, after 12 weeks and after 24 weeks of treatment. Forty-two patients completed the study (14 per group). At baseline, the mean \pm SEM frequency of menstrual cycles/year (calculated using the ratio of expected menses to observation week, ie, 12 cycles/52 weeks) were $0.21 \pm 0.04,0.22 \pm 0.04$, and $0.29 \pm 0.037$, respectively; at 24 weeks, the frequency of menstrual cycles/year were $0.49 \pm$ $0.08,0.57 \pm 0.08$, and $0.83 \pm 0.082$, respectively $(P=0.0001$ overall effect after all treatments; $P=0.018 \mathrm{MET}+\mathrm{EXE}$ vs MET; $P=0.091 \mathrm{MET}+\mathrm{EXE}$ vs EXE). For patients randomized to MET, EXE $10 \mu \mathrm{g}$ or MET + EXE the ovulation rates were 29\% (4/14 patients), 50\% (7/14), and 86\% (12/14), respectively. At baseline, the mean \pm weight was $113.4 \pm 7 \mathrm{~kg}$, $110.5 \pm 6 \mathrm{~kg}$, and $112 \pm 8 \mathrm{~kg}$, respectively; at 24 weeks, the mean $\pm \mathrm{SE}$ weight loss was $1.6 \pm 0.2 \mathrm{~kg}, 3.2 \pm 0.1 \mathrm{~kg}$, and $6 \pm 0.5 \mathrm{~kg}$, respectively $(P=0.001$ for overall effect after all treatments; $P=0.019$ for both groups with EXE vs MET monotherapy). Total testosterone and free androgen index were reduced in all groups $(P \leq 0.05$ overall effect after all treatments) but SHBG (sex hormone binding globulin) and DHEAS (dehydroepiandrosterone sulfate) remained unchanged. Seven of 11 women with glucose intolerance at baseline had normal glucose at 24 weeks (3/5 on MET, 1/3 on EXE, and 3/3 on MET + EXE). HOMA-IR and insulin sensitivity as determined by a 75 -g oral glucose tolerance test, improved in all groups $(\mathrm{P} \leq 0.05$ overall effect after all treatments); insulin sensitivity improved most in those who received MET + EXE vs EXE $(P=0.022)$ but not vs MET. The most frequent AEs for those in MET, EXE, and MET + EXE groups included nausea (4/20,3/20, and 9/20) and diarrhea (6/20, 0/20, and 2/20). Pregnancy occurred in 2/20, $1 / 20$, and $1 / 20$ patients, respectively.

\section{Efficacy with rosiglitazone and pioglitazone}

Pinelli et $\mathrm{al}^{43}$ performed a meta-analysis to compare the effects of adding EXE vs TZDs on glycemic control and tolerability. The studies used in this analysis compared either TZDs or EXE with comparable controls, but not in combination with each other so that the difference due to TZDs or to EXE relative to the control could be estimated. The magnitudes of the changes were then compared between TZDs and EXE to evaluate the difference between the two drug classes. Twenty-two publications were used in the analysis: 8 TZD and 3 EXE studies evaluated the respective agents in combination with MET, SU, SU + MET in a double-blind, placebo-controlled fashion; 9 TZD and 2 EXE studies compared the efficacy of the respective agents with other glucose-lowering agents and open-label SC insulin (glargine and biphasic aspart). ${ }^{43}$

The reduction in $\mathrm{HbA}_{1 \mathrm{c}}$ (weighted mean differences) when patients received TZD-based regimens vs EXE-based regimens was $-0.80 \%$ [95\% CI -1.10 to -0.50$]$ vs $-0.60 \%$ [95\% CI -1.04 to -0.16$]$, respectively. In studies where the comparator was a $\mathrm{PCB}$, the reduction (weighted mean differences) in $\mathrm{HbA}_{1 \mathrm{c}}$ for those who received TZDs vs PCB was $-1.14 \%$ [ $95 \%$ CI -1.30 to -0.98 ] vs $-0.97 \%$ [95\% CI -1.11 to -0.83 ]. No difference in reduction of $\mathrm{HbA}_{1 \mathrm{c}}$ was seen with use of EXE vs insulin $(-0.08$ [95\% CI -0.23 to 0.07$]$ ), but a significant reduction in $\mathrm{HbA}_{1 \mathrm{c}}$ seen in favor of TZD vs active controls $(-0.38[95 \% \mathrm{CI}-0.75$ to $-0.01]$ ). The odds ratio (OR) of reaching $\mathrm{HbA}_{1 \mathrm{c}}<7 \%$ was 2.27 [ $95 \%$ CI 1.22 to 4.24 ] vs 2.90 [95\% CI 1.28 to 6.55], for those who received TZD-based regimens vs EXE-based regimens, respectively. ${ }^{43}$ Compared with $\mathrm{PCB}$, treatment with TZD or EXE increased OR of reaching $\mathrm{HbA}_{1 \mathrm{c}}<7 \%$ (OR 3.72 [95\% CI 2.80 to 4.93]) and (OR 5.72 [95\% CI 3.87 to 8.46]), respectively; however, this effect on OR was not seen when compared with active treatment: TZD vs active controls (OR 1.40 [95\% CI 0.71 to 2.75]) and EXE vs insulin (OR 1.15 [95\% CI 0.73 to 1.80$]$ ), respectively. ${ }^{43}$ 
The pooled OR of developing nonsevere hypoglycemia after exposure to TZD-based regimens was not significantly different from other treatment arms (OR 1.59 [95\% CI 0.76 to 3.32]). In 3 EXE, placebo-controlled studies, ${ }^{36-38}$ the risk of hypoglycemia did not achieve significance (OR 3.53 [95\% CI 0.92 to 13.61]). The change in body weight from baseline for those who received TZDs was nonsignificant vs comparator groups (weighted mean difference $1.51 \mathrm{~kg}$ [95\% CI -0.12 to 3.15]). Mean change in body weight was reduced significantly in patients who received EXE-based regimens (weighted mean difference $-2.74 \mathrm{~kg}$ [95\% CI -4.85 to -0.64$]$ ); the reduction in body weight for those who received EXE in the three placebo-controlled studies ${ }^{36-38}$ was $-1.29 \mathrm{~kg}[95 \%$ CI -2.22 to -0.36$]$ and $-4.79 \mathrm{~kg}$ [95\% CI -6.06 to -3.52$]$ for those who received insulin as the active comparator. The pooled OR for the reporting of GI adverse events (nausea, vomiting, diarrhea) by those receiving EXE-based regimens was 9.02 [ $95 \%$ CI 3.66 to 22.23], 4.56 [ $95 \%$ CI3.13 to 6.65], and 2.96 [ $95 \%$ CI 2.05 to 4.26 ], respectively.

Zinman et $\mathrm{al}^{44}$ conducted a randomized, double-blind, 16-week study to determine the effects on glycemic control by the addition of EXE to TZDs (with or without MET) vs TZDs + PCB. After a 2-week PCB lead-in period where all patients injected PCB SC BID 15 min before the morning and evening meals, patients randomized to EXE began active treatment $(5 \mu \mathrm{g}$ BID for 4 weeks followed by $10 \mu \mathrm{g}$ BID for 12 weeks). All patients received a TZD (rosiglitazone, $\geq 4 \mathrm{mg}$ /day, or pioglitazone, $\geq 30 \mathrm{mg} /$ day). Patient demographics, withdrawals, glycemic measurements, and adverse events are found on Table 7. Compared with PCB, patients receiving EXE + TZD reported a statistically significant reduction in $\mathrm{HbA}_{1 \mathrm{c}}$, fasting serum glucose, daily mean postprandial glucose excursions, and body weight, $P<0.001$ for all comparisons. The change in $\mathrm{HbA}_{1 \mathrm{c}}$ did not vary based on existing oral antihyperglycemic treatment at baseline ( $P=0.87$ for interaction). Postprandial glucose excursions were significantly reduced for patients receiving EXE (mean \pm SE AM change $-1.73 \pm 0.27 \mathrm{mmol} / \mathrm{L}$ and PM change $-1.68 \pm 0.30 \mathrm{mmol} / \mathrm{L}, P<0.001$ vs $\mathrm{PCB}$ for both time points). $\beta$-cell function improved by $19 \%$ for those who received EXE vs a reduction of $6 \%$ for those who received $\operatorname{PCB}(P=0.005)$; insulin sensitivity increased by $23 \%$ in the EXE group vs $10 \%$ in the PCB group at week $16(P=0.20)$. There was a significant reduction in body weight seen in patients receiving EXE starting from week $4(P<0.01$ vs PCB) to week $16(P<0.001 \mathrm{vs} P C B)$. The reductions in weight occurred to a similar extent in those with and without nausea: mean \pm SE change $-1.95 \pm 0.43 \mathrm{~kg}$ and -1.25 $\pm 0.35 \mathrm{~kg}$, respectively. Adverse events occurred in $76 \%$ vs $65.2 \%$ of patients in the EXE vs PCB group (difference EXE $-\mathrm{PCB}=10.9[95 \% \mathrm{CI}-1.7$ to 23.4$]$ ) (Table 7). Nausea and vomiting were common AEs reported by those receiving EXE vs $\mathrm{PCB}$ with 11 patients discontinuing the study due to nausea and 2 discontinuations due to vomiting; however, the investigators felt that the nausea experienced by patients who received EXE was mostly mild $(n=21$ [44\%]) or moderate $(\mathrm{n}=19$ [40\%]) and intermittent.

In summary, the above meta-analysis showed that the use of TZDs may provide a slight advantage over EXE in improving $\mathrm{HbA}_{1 \mathrm{c}}$ along with increased weight gain; those who received EXE lost weight, but experienced more GI adverse effects. The authors reported that the studies (TZDs vs EXE studies) used to determine the effect of the agents on $\mathrm{HbA}_{1 \mathrm{c}}$ were different and 2 points should be taken into consideration: 1) more patients in TZDs studies had baseline $\mathrm{HbA}_{1 \mathrm{c}} \geq 9 \%$ vs $0 \%$ of patients in EXE studies; and, 2) studies with EXE reported using maximally effective doses of SU/MET and EXE vs only half of the studies of TZDs reported use of maximally effective background therapy and TZD dosages. ${ }^{43}$

One study compared the effect of glycemic control and tolerability of adding EXE $10 \mu \mathrm{g}$ BID to TZD $\pm \mathrm{MET}^{44}$ Over 16 weeks, patients randomized to EXE reported a reduction in $\mathrm{HbA}_{1 \mathrm{c}}$ of $0.89 \%$ vs TZD \pm MET, fasting serum glucose of $-1.59 \mathrm{mmol} / \mathrm{L}$, postprandial glucose of $1.58 \mathrm{mmol} / \mathrm{L}$, and body weight of $-1.75 \mathrm{~kg}(P \leq 0.001$ for all comparisons vs PCB). Nausea, vomiting, nasopharyngitis and hypoglycemia were the most commonly reported AEs for those randomized to EXE vs TZDs $(93 / 121$ or $77 \%$ vs $35 / 112$ or $31 \%)$.

\section{Efficacy with insulins}

Heine et $\mathrm{al}^{45}$ conducted a multicenter, randomized, open-label, phase 3 clinical study to compare the effects of EXE vs insulin glargine (GLA) over 26 weeks in patients with type 2 DM receiving $\mathrm{SU}+\mathrm{MET}$. Patients randomized to EXE received $5 \mu \mathrm{g}$ SC BID for 4 weeks with an increase to $10 \mu \mathrm{g}$ SC BID for 22 weeks. Patients randomized to GLA initially received 10 units/day and self-titrated by 2 units every 3 days to achieve a fasting blood glucose target level $<5.6 \mathrm{mmol} / \mathrm{L}$. MET and SU doses were fixed at prestudy levels unless patients experienced hypoglycemia; if this AE occurred, a 50\% reduction in SU dose was recommended. Severity of AE (mild, moderate, or severe) and its attribution to therapy (yes, no) were assessed by the investigator. Patients from 21 sites participated in a meal study where glucose levels were determined before a meal (fasting) and 1 to 4 hours after the meal. The noninferiority 
Table 7 Patient demographics and mean changes from baseline in glycemic control and reported adverse events after the addition of exenatide to TZD \pm metformin therapy after 16 weeks $^{44}$

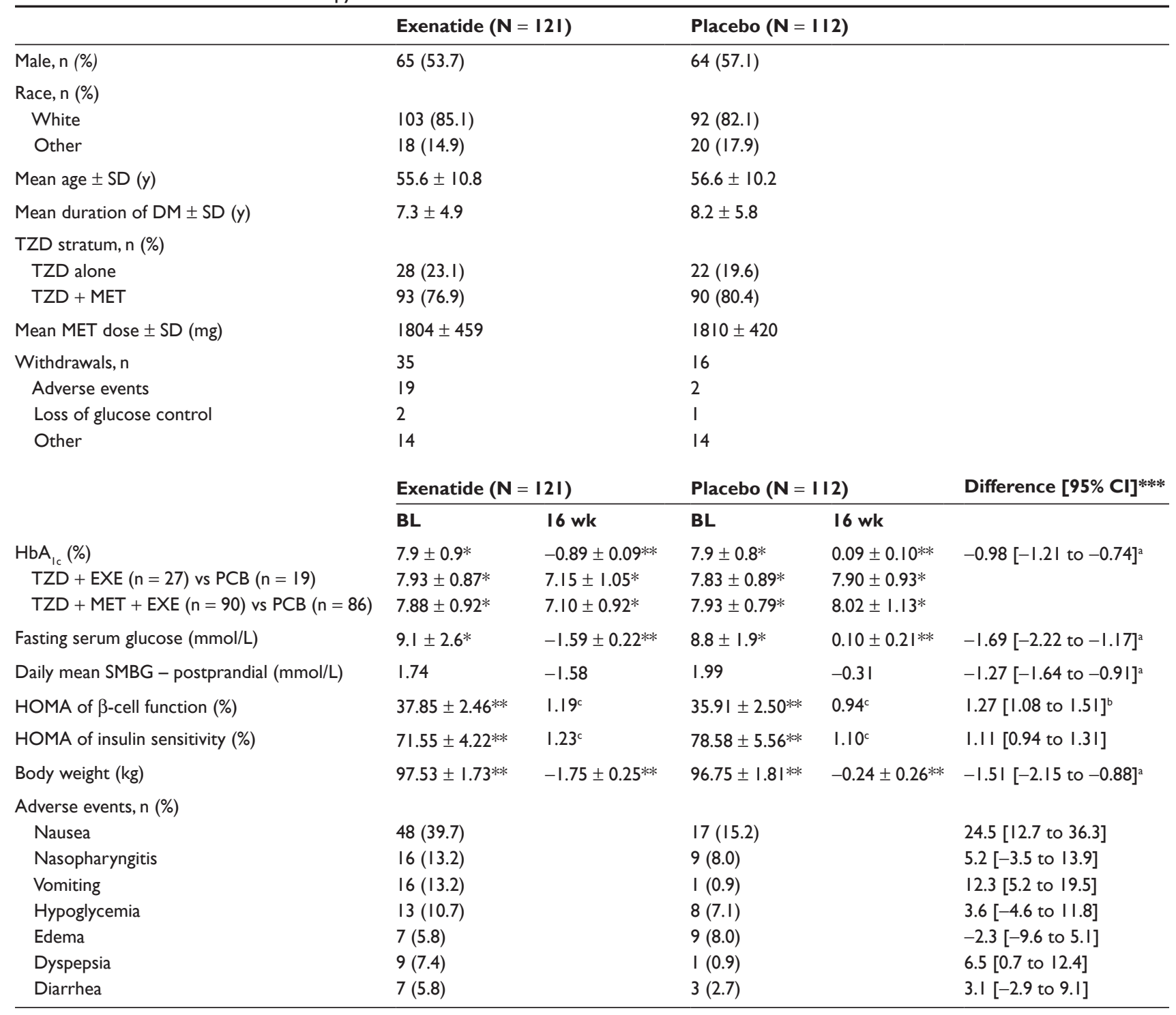

Notes: $*$ Mean $\pm \mathrm{SD}$; ${ }^{* *}$ mean $\pm \mathrm{SE} ;{ }^{* * *}$ difference (reported in percentage points) is calculated as $\mathrm{EXE}$ (exenatide) minus $\mathrm{PCB}$; ${ }^{\text {a }} \mathrm{P} \leq 0.00 \mathrm{I}$ vs $\mathrm{PCB} ;{ }^{\mathrm{b}} \mathrm{P}=0.005$ vs $\mathrm{PCB} ;{ }^{\mathrm{c}} \mathrm{Changes}$ in HOMA of $\beta$-cell function and HOMA of insulin sensitivity were performed on log-transformed data where the analysis variable was a change [log(final)-log (baseline)] and where back-transformations were expressed as ratios.

Abbreviations: $\mathrm{BL}$, baseline; $\mathrm{HbA}_{\mathrm{Ic}}$ hemoglobin $\mathrm{A}_{\mathrm{Ic}}$; $\mathrm{SMBG}$, self-monitoring of blood glucose; $\mathrm{HOMA}$, homeostasis model assessment; $\mathrm{MET}$, metformin; TZD, thiazolidinedione; PCB, placebo.

margin for the difference between treatments (EXE minus GLA) on $\mathrm{HbA}_{1 \mathrm{c}}$ was defined as $0.4 \%$.

Patient demographics for those in the EXE group $(\mathrm{N}=282)$ and GLA group $(\mathrm{N}=267)$ were as follows: $55 \%$ males; 79.8\% Caucasians, $15.6 \%$ Hispanics; mean \pm SD age $59.8 \pm 8.8$ years; mean \pm SD duration of DM 9.9 \pm 6.0 years and 56.6\% males; $80.5 \%$ Caucasians, 15.0\% Hispanics; $58.0 \pm 9.5$ years of age; duration of DM $9.2 \pm 5.7$ years. Results of glycemic control and body weight are found on Table 8 . At 26 weeks, patients in both groups achieved a similar reduction in $\mathrm{HbA}_{1 \mathrm{c}}$ with similar percentages reaching $\mathrm{HbA}_{1 \mathrm{c}} \leq 7 \%$ (46\% vs $48 \%$ ), respectively. The average GLA at week 26 was 25 units/day $(\mathrm{N}=244)$, and $21.6 \%$ of those in the GLA group vs $8.6 \%$ of those in the EXE group achieved a FPG $<5.6 \mathrm{mmol} / \mathrm{dL}, P<0.001$ vs EXE. Patients in the EXE group began to lose weight within 2 weeks of therapy vs weight gain by those in the GLA group $(P<0.0001)$; weight loss by those in the EXE group who did not report nausea $(\mathrm{n}=120)$ was $-1.9 \mathrm{~kg}$ [CI -2.5 to $-1.4 \mathrm{~kg}$ ] and was similar for those who did 
Table 8 Mean changes from baseline in $\mathrm{HbA}_{1 \mathrm{c}}$, fasting glucose, and body weight in patients (intention-to-treat) receiving exenatide vs insulins $\mathbf{s}^{45,47,48}$

\begin{tabular}{|c|c|c|c|c|}
\hline \multirow[b]{2}{*}{ Heine et $\mathrm{al}^{45}$} & \multicolumn{4}{|l|}{$\mathrm{HbA}_{\mathrm{Ic}}(\%)$} \\
\hline & $\mathrm{BL}$ & Wk 26 & \multicolumn{2}{|c|}{$\begin{array}{l}\text { Difference between the groups } \\
{[95 \% \mathrm{Cl}]^{\mathrm{a}}}\end{array}$} \\
\hline $\operatorname{EXE}(\mathrm{N}=275)$ & $8.2 \pm 1.0$ & $-1.1 I^{b, c}$ & \multicolumn{2}{|l|}{0.017} \\
\hline GLA $(N=260)$ & $8.3 \pm 1.0$ & $-1.1 I^{b, c}$ & \multicolumn{2}{|c|}{$[-0.123$ to 0.157$]$} \\
\hline Nauck et $\mathrm{al}^{47}$ & $\mathrm{BL}$ & Wk 52 & \multicolumn{2}{|l|}{-0.15} \\
\hline $\operatorname{EXE}(N=253)$ & $8.6 \pm 1.0$ & $-1.04 \pm 0.07^{\mathrm{b}, \mathrm{d}, \mathrm{e}}$ & \multicolumn{2}{|c|}{$[-0.32$ to 0.01$],(P=0.067)$} \\
\hline \multirow[t]{2}{*}{ BIASP $(N=248)$} & $8.6 \pm 1.1$ & $-0.89 \pm 0.06^{\mathrm{b}, \mathrm{d}, \mathrm{e}}$ & & \\
\hline & \multicolumn{4}{|c|}{ Fasting glucose (mmol/L) } \\
\hline Heine et $\left.\mathbf{a}\right|^{45}$ & $\mathrm{BL}$ & Wk 26 & \multicolumn{2}{|c|}{$\begin{array}{l}\text { Difference between the groups } \\
{[95 \% \mathrm{Cl}]^{\mathrm{a}}}\end{array}$} \\
\hline $\operatorname{EXE}(N=275)$ & $10.1 \pm 2.6$ & -1.4 & \multicolumn{2}{|l|}{-1.5} \\
\hline GLA $(N=260)$ & $10.4 \pm 2.9$ & $-2.9^{f}$ & \multicolumn{2}{|c|}{$[-1.1$ to -1.9$]$} \\
\hline Nauck et al $\left.\right|^{47}$ & $\mathrm{BL}$ & Wk 52 & \multicolumn{2}{|l|}{-0.1} \\
\hline $\operatorname{EXE}(N=253)$ & $1 \mathrm{I} .0 \pm 2.7$ & $1.8 \pm 0.2^{\mathrm{d}, \mathrm{e}}$ & \multicolumn{2}{|c|}{$[-0.6$ to 0.4$],(P=0.689)$} \\
\hline \multirow[t]{2}{*}{ BIASP $(N=248)$} & $11.3 \pm 2.8$ & $-1.7 \pm 0.2^{\mathrm{d}, \mathrm{e}}$ & & \\
\hline & \multicolumn{4}{|c|}{ Body weight (kg) } \\
\hline Heine et al $^{45}$ & $B L$ & Wk 26 & \multicolumn{2}{|c|}{$\begin{array}{l}\text { Difference between the groups } \\
{[95 \% \mathrm{Cl}]^{\mathrm{a}}}\end{array}$} \\
\hline $\operatorname{EXE}(N=275)$ & $87.5 \pm 16.9$ & $-2.3^{f}$ & \multicolumn{2}{|l|}{-4.1} \\
\hline GLA $(N=260)$ & $88.3 \pm 17.9$ & 1.8 & \multicolumn{2}{|c|}{$[-4.6$ to -3.5$]$} \\
\hline Nauck et al ${ }^{47}$ & $\mathrm{BL}$ & Wk 52 & \multicolumn{2}{|l|}{-5.4} \\
\hline $\operatorname{EXE}(N=253)$ & $85.5 \pm 15.7$ & $-2.5 \pm 0.2^{\mathrm{d}, \mathrm{e}}$ & \multicolumn{2}{|c|}{$[-5.9$ to -5.0$],(P<0.00 \mathrm{I})$} \\
\hline \multirow[t]{2}{*}{ BIASP $(N=248)$} & $83.4 \pm 15.6$ & $+2.9 \pm 0.2^{\mathrm{d}, \mathrm{e}}$ & & \\
\hline & Exenatide & & \multicolumn{2}{|c|}{ Insulins (N = 5 I5) } \\
\hline Glass et $\mathrm{al}^{48, \mathrm{~h}}$ & BL, n (\%) & Endpoint, n (\%) & BL, n (\%) & Endpoint, n (\%) \\
\hline BMI $<25$ & $20(3.8)$ & $5 I(9.6)^{i, j}$ & $27(5.2)$ & $20(3.9)$ \\
\hline BMI 25-29 & $220(4 \mid .4)$ & $222(4 \mid .7)$ & $227(44.1)^{i}$ & $2 \mid 3(4 \mid .4)$ \\
\hline $\mathrm{BMI} \geq 30$ & $292(54.9)$ & $259(48.7)^{i, j}$ & $26 I(50.7)^{i}$ & $282(54.8)^{i}$ \\
\hline
\end{tabular}

Notes: Values presented as mean $\pm \mathrm{SD}$, unless otherwise noted a Exenatide minus insulin; ${ }^{\mathrm{b}}$ Percentage points; ${ }^{\mathrm{c}}$ Change from baseline (least-squares means are obtained from a statistical model that includes baseline as a covariate); dMean (SEM) (least-squares mean changes were obtained from a mixed model repeated-measures anaysis of covariance); ${ }^{e} P<0.00$ I for BL to week 52 within-group change; ${ }^{f} P<0.000$ I in favor of EXE; ${ }^{P} P<0.00$ I in favor of GLA; ${ }^{\text {Pooled }}$ post-hoc analysis of Heine et al and Nauck et al; iP $\leq 0.000$ I vs $B L ; ' P<0.000 I$ vs insulin.

Abbreviations: BIASP, biphasic aspart (30\% rapid-acting aspart); BMI, body mass index, $\mathrm{kg} / \mathrm{m}^{2}$; $\mathrm{EXE}$, exenatide; GLA, glargine; $\mathrm{HbA}_{\mathrm{lc}}$, hemoglobin $\mathrm{A}_{\mathrm{lc}}$

report nausea (data not provided). Patients receiving GLA had lower glucose levels at fasting $(P<0.001)$, before meals (prelunch, $P=0.023$; predinner, $P=0.006$ ), and at 03:00 h $(P<0.001)$, but they had higher glucose levels after morning $(P<0.001)$ and evening meals $(P<0.001)$ vs EXE. Those receiving EXE reported lower glucose levels after the morning $(P<0.001)$ and evening $(P<0.001)$ meals vs GLA. The change in total glucose 4-hour AUC (from baseline) after the test meal study for those in the EXE $(n=41)$ vs GLA $(n=37)$ groups was similar between the two groups: $-12.9 \mathrm{mmol} \cdot \mathrm{h} / \mathrm{L}$ vs $-13.3 \mathrm{mmol} \cdot \mathrm{h} / \mathrm{L}$ [CI -4.0 to $4.7 \mathrm{mmol} \cdot \mathrm{h} / \mathrm{L}]^{45}$
A total of 54 vs 25 patients in the EXE vs GLA groups withdrew from the study. Reasons included AEs (27 vs 2) and loss of glucose control (4 vs 0 ); 23 patients from both groups withdrew due to protocol violations or were lost to follow-up. The most common AEs by those in the EXE vs GLA group included nausea (57.1\% vs $8.6 \%, \mathrm{P}<0.001)$, vomiting $(17.4 \%$ vs $3.7 \%$, $P<0.001)$, diarrhea (8.5\% vs $3.0 \%, P=0.006)$, upper abdominal pain ( $4.3 \%$ vs $0.7 \%, P=0.012)$, constipation (3.5\% vs $0.4 \%, P=0.011)$, dyspepsia $(3.5 \%$ vs $0.4 \%$, $P=0.011)$, anorexia (3.5\% vs $0 \%, P=0.002)$ and decreased appetite $(3.2 \%$ vs $0.4 \%, P=0.021)$; indeed, $55 \%$ in this 
group reported $\geq 1$ episode of nausea during the first 2 months and $13 \%$ reported nausea during the last 2 months of the study $(32.6 \%, 19.9 \%$, and $4.6 \%$ with mild, moderate, or severe intensity); 18 patients (vs 1 in GLA group) withdrew due to nausea. The overall rate of hypoglycemia was similar across treatment groups (7.3 events/patientyear vs 6.3 events/patient-year in the EXE vs GLA group [difference $1.1 \mathrm{CI}-1.3$ to 3.4 events/patient-year]). The rate of nocturnal hypoglycemia was 0.9 events/patient-year vs 2.4 events/patient-year [difference $-1.6 \mathrm{CI}-2.3$ to -0.9 events/patient-year], respectively. The rate of daytime hypoglycemia was 6.6 events/patient-year vs 3.9 events/ patient-year [difference 2.7 CI 0.4 to 4.9 events/patientyear], respectively. The percent of patients who achieved a $\mathrm{HbA}_{1 \mathrm{c}} \leq 7 \%$ and reported a symptomatic hypoglycemic episode was $61 \%$ vs $68 \%$, respectively; $21 \%$ vs $43 \%$ reported an episode of nocturnal hypoglycemia. ${ }^{45}$

A secondary analysis of the above-mentioned study ${ }^{45}$ was conducted by Boye et $\mathrm{al}^{46}$ determined the effect of treatment on change in patient-reported health outcomes measures. Five health outcomes instruments were completed at baseline (week 0) and endpoint (week 26). These were: 1) Diabetes Symptom Checklist-revised (DSC-R) which measured the frequency and perceived discomfort of physical and psychological symptoms associated with type 2 diabetes and its potential complications; 2) Diabetes Treatment Flexibility Scale (TFS) which evaluated how much choice patients have in their decisions concerning meals and physical, social, and other daily activities during the past month; 3) Diabetes Treatment Satisfaction questionnaire (DTSQ) which measured diabetes treatment regimens among patients with type 1 and type 2 DM; 4) EuroQol EQ-5D which provided an estimate of overall health status; and 5) Vitality scale of the SF-36 which assessed energy level and fatigue. When compared with baseline scores, both agents caused a significant improvement in DSC-R overall score, DTS score, SF-36 Vitality subscale score, DSC-R Psychology Fatigue and Cognitive scores, DSC-R Ophthalmology score, DSC-R Hypoglycemia score, DSC-R Hyperglycemia score, DTSQ Frequency High Blood Sugar and Low Blood Sugar scores ( $P \leq 0.04$ for all vs baseline). However, there was not a statistically significant difference between the two groups in change in health outcomes.

Nauck et $\mathrm{al}^{47}$ conducted a multicenter, randomized, open-label, non-inferiority study to compare the effects of EXE vs biphasic aspart 30/70 (30\% rapid-acting aspart, BIASP) over 52 weeks in patients with type 2 DM receiving $\mathrm{SU}+\mathrm{MET}$. Patients randomized to EXE received $5 \mu \mathrm{g} \mathrm{SC}$
BID for 4 weeks with an increase to $10 \mu \mathrm{g}$ SC BID for the duration of the study; if frequent nausea developed (daily episodes $>1$ week duration), patients had the option to decrease their dose to $5 \mu \mathrm{g}$ BID. Patients randomized to insulin BIASP initially received an amount determined by their physicians; a forced titration schedule was not used in the study, and investigators were instructed to adjust insulin doses to achieve an optimal balance between glucose control and risk of hypoglycemia. MET and SU doses were maintained at optimally effective prestudy levels unless patients experienced hypoglycemia; if this AE occurred, a 50\% reduction in SU dose was recommended. Severity of AE (mild, moderate, or severe) and its attribution to therapy (yes, no) were assessed by the investigator. The non-inferiority margin for the difference in $\mathrm{HbA}_{1 \mathrm{c}}$ change between treatments was predefined as $0.4 \%$, with non-inferiority demonstrated by excluding the $0.4 \%$ noninferiority margin with the upper limit of a two-sided 95\% CI for the mean difference between treatment. ${ }^{47}$

Patient demographics for those in the EXE group $(\mathrm{N}=253)$ and BIASP group $(\mathrm{N}=248)$ were as follows: $53 \%$ males; mean \pm SD age $59.0 \pm 9.0$ years; mean $\pm \mathrm{SD}$ duration of DM $9.8 \pm 6.3$ years and $49 \%$ males; $58.0 \pm 9.0$ years of age; duration of DM $10.0 \pm 6.2$ years. Results of glycemic control and body weight are found on Table 8 . At 52 weeks, $80 \%$ of patients in the EXE group (195/245) were using $10 \mu \mathrm{g}$ BID and the mean dose of BIASP increased from $15.7 \pm 9.5$ units/day at week 2 to $24.4 \pm 15.6$ units/day. More patients in the EXE group had SU dose reduced during the study ( $33 \%$ vs 5\%), respectively. Based on the change of $\mathrm{HbA}_{1 \mathrm{c}}$, treatment with EXE was noninferior to treatment with BIASP. More patients in the EXE group achieved $\mathrm{HbA}_{1 \mathrm{c}} \leq 7 \%(32 \%$ vs $24 \%, P=0.038)$. Based on SMBG (premeals, 2 hours postmeals, and 03:00 h), both groups reduced glucose levels at all time points (all within group values, $P<0.001$ ); BIASP group had significantly lower mean glucose values prebreakfast $(P=0.037)$, prelunch $(P=0.004)$, and 03:00 h $(P=0.002)$; patients randomized to EXE reported lower 2-hour postbreakfast $(P<0.001)$ and postsupper $(P<0.001)$ mean glucose values. Patients in the EXE group began to lose weight at week 2 and progressed to a difference of $-5.5 \pm 0.2 \mathrm{~kg}$ (least-squares mean $\pm \mathrm{SEM}$, $95 \% \mathrm{CI}-5.9$ to $-5.0 \mathrm{~kg}, P<0.001)$ vs BIASP at week 52 . The weight loss for those who were on EXE and had $\geq 1$ episode of nausea or vomiting vs those without nausea/vomiting was similar at $-2.7 \pm 3.2 \mathrm{~kg}, \mathrm{n}=94$ and $-2.1 \pm 3.4 \mathrm{~kg}$, $\mathrm{n}=157$, respectively. A statistically significant mean reduction in both systolic $(-5 \pm 15 \mathrm{mmHg}, P<0.001 \mathrm{vs} \mathrm{BL})$ 
and diastolic $(-2 \pm 10 \mathrm{mmHg}, P=0.03 \mathrm{vs} \mathrm{BL})$ blood pressure was reported for those receiving EXE but not BIASP. ${ }^{47}$

Of 501 randomized patients, 199 patients in the EXE and 223 patients in the BIASP groups completed the study; 20/54 patients in the EXE withdrew due to AEs vs 0/25 in the BIASP group. The most commonly reported AEs for those in the EXE (ITT sample $\mathrm{N}=253$ ) vs BIASP (ITT sample $\mathrm{N}=248$ ) groups, included nausea $(33.2 \% \mathrm{vs}$ $0.4 \%$ ), vomiting (15.0\% vs $3.2 \%$ ), nasopharyngitis $(11.1 \%$ vs $9.7 \%$ ), and diarrhea (9.5\% vs $2.0 \%)$. In total, $5.1 \%$ of patients withdrew from the EXE group due to GI AEs. The overall hypoglycemia rates (least-square means \pm SEM) at endpoint for those in the EXE vs BIASP groups were $4.7 \pm 0.7$ events/patient-year vs $5.6 \pm 0.7$ events/patientyear, respectively; the rates of daytime and nocturnal hypoglycemia was similar between the 2 groups and the overall hypoglycemia rates decreased when SU doses were lowered for those receiving EXE (mean $\pm \mathrm{SD}$ : before $\mathrm{SU}$ reduction, $26.9 \pm 43.3$ events/patient-year; after SU reduction, $6.1 \pm 8.3$ events/patient-year); data about SU doses for BIASP group not provided. ${ }^{47}$

Glass et $\mathrm{al}^{48}$ pooled data from the above two studies, ${ }^{45,47}$ to analyze the effect of EXE vs insulins (GLA or BIASP) on weight after 6 months of treatment. Patient demographics for those receiving EXE were as follows: $\mathrm{N}=532$, mean $\pm \mathrm{SD}$ age $59.4 \pm 8.8$ years, $54.3 \%$ males, $87 \%$ Caucasians and $8.3 \%$ Hispanics, $9.9 \pm 6.1$ years with DM; for those in the INS group, $\mathrm{N}=515,58.2 \pm 9.3$ years, $53 \%$ males, 86.6\% Caucasians and 7.8\% Hispanics, with 9.6 \pm 6.0 years with DM. Patient classification based on weight and study agent can be found on Table 8 . At 6 months, both groups reported a significant reduction in $\mathrm{HbA}_{1 \mathrm{c}}(\mathrm{EXE}$ : $-1.06 \pm 0.05, P<0.0001$ vs BL; INS: $-1.05 \pm 0.04$, $P<0.0001$ vs BL). Those treated with EXE had an average weight loss of $2.3 \mathrm{~kg}$ and those treated with INS gained an average of $1.8 \mathrm{~kg}$. At endpoint, a higher number of patients in the EXE group reported a BMI $<25 \mathrm{~kg} / \mathrm{m}^{2}(P<0.0001$ vs $\mathrm{BL}$ and $P<0.0001$ vs INS) and a smaller number of patients reported a $\mathrm{BMI} \geq 30 \mathrm{~kg} / \mathrm{m}^{2}(P<0.0001$ vs $\mathrm{BL}$ and $P<0.0001$ vs INS); more patients in the INS group reported a $\mathrm{BMI} \geq 30 \mathrm{~kg} / \mathrm{m}^{2}$ vs $\mathrm{BL}(P<0.0001){ }^{48}$

\section{Tolerability}

None of the studies reviewed reported toxicity to any major organs or clinically significant changes in laboratory test results, physical findings, diagnostic testing or vital signs. Nausea, hypoglycemia, vomiting and nasopharyngitis ${ }^{44}$ were the most commonly reported adverse drug events. ${ }^{36-47}$
Nausea was most frequently $(>20 \%)$ reported in patients receiving the highest dose of EXE (10 $\mu \mathrm{g} \mathrm{SC}$ BID vs $5 \mu \mathrm{g}$ SC BID). ${ }^{36-47}$ Hypoglycemia was mostly reported in patients receiving the combination treatment of sulfonylurea + metformin $+\operatorname{EXE}(>30 \%)^{38}>$ sulfonylurea alone $(>15)^{36}>$ metformin alone $(\geq 5 \%) .{ }^{37}$ To minimize these common GI and hypoglycemia adverse events, EXE dose escalation is recommended. ${ }^{20,49}$

The FDA issued an update on November 18, 2008 about new cases of hemorrhagic/necrotizing pancreatitis (HNP) in patients taking EXE. ${ }^{50}$ Between June 2005 and July 2007, the cumulative spontaneous reporting rate of HNP is 0.20 events per 1000 patient-years of exposure. Patients at a high risk for experiencing HNP while receiving EXE include patients with a history of gall stones, hypertriglyceridemia and excess alcohol intake. Symptoms of HNP are persistent severe abdominal pain with or without excessive nausea and vomiting while receiving EXE therapy. The FDA has advised healthcare professionals to instruct their patients to seek immediate medical attention if these symptoms commence suddenly while receiving EXE. ${ }^{50}$

\section{Dosing and administration}

In the US, EXE is supplied as a sterile solution for subcutaneous injection in $1.2 \mathrm{~mL}(5 \mu \mathrm{g} / 0.2 \mathrm{~mL}, 60$ doses $)$ and $2.4 \mathrm{~mL}(10 \mu \mathrm{g} / 0.4 \mathrm{~mL}, 60$ doses $)$ prefilled pens. ${ }^{20}$ Each milliliter of EXE contains $250 \mu \mathrm{g}$ of synthetic EXE, mannitol as atonicily-adjusting agent, 2.2 metacresol as an antimicrobial preservative, and glacial acetic acid/sodium acetate trihydrate as a buffering solution $(\mathrm{pH}=4.5) .{ }^{20} \mathrm{EXE}$ should be administered as a $\mathrm{SC}$ injection in the thigh, abdomen or upper arm within the 60 -min period before the morning and evening meals. EXE should not be administered after meals. The recommended starting dose is $5 \mu \mathrm{g}$ SC BID. EXE dose can be titrated up to $10 \mu \mathrm{g}$ SC BID after 1 month of therapy with the $5 \mu \mathrm{g}$ SC BID regimen. EXE prefilled pens should be kept refrigerated and not frozen until first use. Once used, the prefilled pens can be kept in the refrigerator or at room temperature not exceeding $77^{\circ} \mathrm{F}\left(25^{\circ} \mathrm{C}\right)$ for up to 30 days. ${ }^{20}$

The use of EXE is contraindicated in patient with known hypersensitivity to the drug or any of its components. EXE is listed as a pregnancy category $\mathrm{C}$ drug and should be used during pregnancy only if the potential benefits outweigh the risk to the fetus. It is unknown whether EXE is excreted in human milk and therefore, caution should be exercised with nursing women. ${ }^{20}$ 


\section{Pharmacoeconomic considerations}

The average wholesale price of the $1.2 \mathrm{~mL}(5 \mu \mathrm{g} / 0.2 \mathrm{~mL})$ and the $2.4 \mathrm{~mL}(10 \mu \mathrm{g} / 0.4 \mathrm{~mL})$ prefilled pens are US $\$ 240.84$ and US\$282.63, respectively. ${ }^{51}$ Both prefilled pens contain enough medication for a month.

The literature search identified one study that evaluated the potential cost effectiveness of treating patients with EXE as an adjunctive therapy in type 2 DM. Minshall et $\mathrm{a}^{52}$ conducted a long-term cost effectiveness study using 30 -year base case assumptions and data from 82 weeks (from 30-week clinical trials +52 weeks of subsequent open-label extensions) to estimate the effects of 30 years of EXE adjunctive treatment in patients with type $2 \mathrm{DM}$. The analysis found that using EXE for 30 years compared with no additional treatment beyond sulfonylurea and/or metformin yields an incremental cost-effectiveness ratio of US $\$ 35,571 . .^{52}$

\section{Discussion}

It appears that when patients received EXE $10 \mu \mathrm{g}$ SC BID in the three, 30-week, placebo-controlled studies with background SUs, MET, or SU + MET, there was a significant reduction in $\mathrm{HbA}_{1 \mathrm{c}}(0.77 \%$ to $0.86 \%)$, fasting plasma glucose $(0.6 \mathrm{mmol} / \mathrm{L})$, and body weight $(1.6$ to $2.8 \mathrm{~kg})(P \leq 0.05$ vs PCB). The beneficial effect of EXE was maintained in patients who completed the two open-label phase trials with an additional 52 weeks of therapy. Gastrointestinal events were seen more commonly in those randomized to EXE with nausea occurring in $43.5 \%$ of patients (419/963 ITT patients receiving EXE) vs $26 \%$ of patients receiving PCB (126/483 ITT patients). More patients receiving EXE $10 \mu \mathrm{g}$ or when patients received concomitant MET therapy complained of nausea vs the $5-\mu \mathrm{g}$ dose or SU monotherapy. Most patients reported nausea and other GI AEs to be mild-to-moderate in severity and $2 \%$ to $4 \%$ of patients receiving EXE withdrew from the study due to nausea. Hypoglycemia occurred in $20 \%(189 / 963)$ vs $9 \%(42 / 483)$ of patients receiving EXE vs PCB; this AE occurred more commonly in those receiving SUs + MET $>$ SUs only $>$ MET only.

The use of TZDs may provide a slight advantage over EXE in improving $\mathrm{HbA}_{1 \mathrm{c}}$ along with increased weight gain; those who received EXE lost weight, but experienced more GI adverse effects. The authors reported that the studies (TZDs vs EXE studies) used to determine the effect of the agents on $\mathrm{HbA}_{1 \mathrm{c}}$ were different and should be taken into consideration. When comparing EXE treatment with insulin treatment, patients receiving EXE lost significant body weight while patients receiving insulin gained weight. Further, patients receiving insulin had lower fasting, prelunch, and predinner glucose levels while patients in the EXE groups exhibited lower postprandial glucose levels.

\section{Future directions}

Long-term, head-to-head studies assessing the effect of the $\mathrm{EXE} \pm$ oral agents/insulins in patients with $\mathrm{HbA}_{1 \mathrm{c}} \geq 10 \%$ are needed to fully clarify the role of this agent in the treatment of poorly managed type $2 \mathrm{DM}$. Additionally, long-term studies evaluating the efficacy and safety of EXE $2 \mu \mathrm{g}$ SC once weekly in patients with type $2 \mathrm{DM}$ and patients with insulin resistance without diabetes are needed.

\section{Conclusions}

EXE, a functional analog of human GLP-1, has been found to regulate glucose-dependent insulin secretion, to reduce postprandial hyperglycemia, to suppress inappropriately high glucagon secretions, to slow down gastric emptying and to reduce food intake/body weight. EXE at the dose of $10 \mu \mathrm{g}$ SC BID has proven to decrease $\mathrm{HbA}_{1 \mathrm{c}}$ by $1.3 \pm 0.1 \%$ and decrease body weight by up to $5.3 \pm 0.8 \mathrm{~kg}$ at week 82 . Nausea was the most frequently reported adverse event $(>20 \%)$ especially in patients being treated with EXE $10 \mu \mathrm{g}$ SC BID. As a result, EXE dose escalation from $5 \mu \mathrm{g}$ SC BID for a month to $10 \mu \mathrm{g}$ SC BID is recommended. While being treated with EXE, patients that experience severe abdominal pain with or without nausea/vomiting, should seek immediate medical attention to rule out hemorrhagic/necrotizing pancreatitis. EXE can be safely added to metformin therapy, sulfonylurea therapy or metformin and sulfonylurea therapy combination to effectively target glycemic goals in patients with type 2 DM. A new formulation of EXE $2 \mathrm{mg}$ sustained release $\mathrm{SC}$ once weekly for the treatment of type 2 diabetes is being study. This new formulation has shown to reduce $\mathrm{HbA}_{1 \mathrm{c}}$ by $1.9 \%$ and body weight by $3.7 \mathrm{~kg}$ at week 30 . This formulation seems to share a similar tolerability profile that EXE SC BID with nausea and vomiting being the most commonly reported adverse events.

\section{Disclosures}

The authors have nothing to disclose.

\section{References}

1. National Diabetes Information Clearinghouse. National Diabetes Statistics, 2007. http://diabetes.niddk.nih.gov/dm/pubs/staTIStics/ DM_Statistics.pdf. Accessed January 3rd, 2009.

2. Khaw KT, Wareham N, Bingham S, et al. Association of hemoglobin A1C with cardiovascular disease and mortality in adults: the European prospective investigation into cancer in Norfolk. Ann Intern Med. 2004;141:413-420. 
3. American Diabetes Association. Direct and indirect costs of diabetes in the United States. http://www.diabetes.org/diabetes-statistics/costof-diabetes-in-us.jsp. Accessed January 3rd, 2009.

4. Wild S, Roglic G, Green A, et al. Global Prevalence of diabetes: estimates for the year 2000 and projections for 2030. Diabetes Care. 2004;27:1047-1053

5. American Diabetes Association. Standards of Medical Care. Diabetes Care. 2009;32(S1):S13-S61.

6. Cook CL, Johnson JT, Wade WE. Diabetes Mellitus. In: Chisholm-Burns M Wells BG, Schwinghammer TL, et al. editors. Pharmacotherapy, Principles and Practice.1st ed. New York, NY: McGraw-Hill; 2008. p. 643-666.

7. Butler AE, Janson J, Bonner-Weir S, et al. Beta-cell deficit and increased beta-cell apoptosis in humans with type 2 diabetes. Diabetes. 2003;52:102-110.

8. Van Gaal LF, De LI. Rationale and options for combination therapy in the treatment of type 2 diabetes. Diabetologia. 2003;46:M44-M50.

9. Van Gaal LF, Gutkin SW, Nauck MA. Exploiting the antidiabetic properties of incretins to treat type 2 diabetes mellitus: glucagon-like peptide 1 receptor agonists or insulin for patients with inadequate gycemic control? Eur J Endocrinol. 2008;158:773-784.

10. Shah P, Vella A, Basu A, et al. Lack of suppression of glucagon contributes to postprandial hyperglycemia in subjects with type 2 diabetes mellitus. J Clin Endocrinol Metab. 2000;85:4053-4059.

11. Toft-Nielsen MB, Damholt MB, Madsbad S, et al. Determinant of impaired secretion of glucagon-like peptide- 1 in type 2 diabetic patients. $J$ Clin Endocrinol Metab. 2001;86:3717-3723.

12. Ali S, Drucker DJ. Benefits and limitations of reducing glucagon action for the treatment of type 2 diabetes. Am J Physiol Endocrinol Metab. 2009;296:E415-E421.

13. Kim W, Egan JM. The role of incretins in glucose homestasis and diabetes treatment. Pharmacol Rev. 2008;60:470-512.

14. Joy SV, Rodgers PT, Scates AC. Incretin mimetics as emerging treatments for type 2 diabetes. Ann Pharmacother. 2005,39:110-118.

15. Nielsen L, Young A, Parkes D. Pharmacology of exenatide (synthetic exendin-4): a potential therapeutic for improved glycemic control of type 2 diabetes. Regulatory Peptides. 2004;117:77-88.

16. Xu G, Kaneto H, Lopez-Avalo MD, et al. GLP-1/exendin-4 facilitates beta-cell neogenesis in rat and human pancreatic ducts. Diabetes Res Clin Pract. 2006;73:107-110.

17. Movassat J, Beattie GM, Lopez AD, et al. Exendin4 up-regulates expression of PDX 1 and hastens differentiation and maturation of human fetal pancreatic cells. J Clin Endocrinol Metab. 2002;87:4775-4781.

18. Liu Z, Habener JF. Glucagon-likePeptide-1 activation of TCF7L2dependent wnt signaling enhances pancreatic beta cell proliferation. J Biol Chem. 2008;283:8723-8735.

19. Chen J, Couto F, Minn AH, et al. Exenatide inhibits beta-cell apoptosis by decreasing thioredoxin-interacting protein. Biochem Biophy Res Comm. 2006;346:1067-1074.

20. Byetta [package insert]. San Diego, Calif: Amylin Pharmaceuticals, Inc; 2008.

21. Kieffer TJ, McIntosh CH, Pederson RA. Degradation of glucose-dependent insulinotropic polypeptide and truncated glucagons-like peptide 1 in vitro and in vivo by depeptidyl peptidase IV. Endocrinol. 1995;136:3585-3596.

22. Linnebjerg H, Kothare PA, Park S, et al. Effect of renal impairment on the pharmacokinetcs of exenatide. Br J Clin Pharmacol. 2007;64: 317-327.

23. Blase E, Taylor K, Gao H, et al. Pharmacokinetics of an oral drug (acetaminophen) administered at various times in relation to subcutaneous injection of exenatide (exendin-4) in healthy subjects. J Clin Pharmacol. 2005;45:570-577.

24. Kothare PA, Soon DK, Linnebjerg H, et al. Effect of exenatide on the steady-state pharmacokinetics of digoxin. J Clin Pharmacol. 2005;45:1032-1037.

25. Soon D, Kothare PA, Linnebjerg H, et al. Effect of exenatide on the pharmacokinetics and pharmacodynamics of warfarin in healthy Asian men. J Clin Pharmacol. 2006;46:1179-1187.
26. Bunck MC, Diamant M, Corner A. One-year treatment with exenatide improves beta-cell function compared to insulin glargine, in metformin treated type 2 diabetes patients: a randomized, controlled trial. Diabetes Care. 2009;32:762-768.

27. Fehse F, Trautman M, Holst JJ, et al. Exenatide augments first- and secondphase insulin secretion in response to intravenous glucose in subjects with type 2 diabetes. J Clin Endocrinol Metab. 2005;90:5991-5997.

28. Linnebjerg H, Kothare PA, Skivanekt A, et al. Exenatide: effect of injection time on postprandial glucose in patients with type 2 diabetes. Diabet Med. 2006;23:240-245.

29. Cervera A, Wajcberg E, Sriwijitkamol A, et al. Mechanism of action of exenatide to reduce postprandial hyperglycemia in type 2 diabetes. Am J Physiol Endocrinol Metab. 2008;294:E846-E852.

30. Kolterman OG, Buse JB, Fineman MS, et al. Synthetic exendin-4 (exenatide) significantly reduces postprandial and fasting plasma glucose in subjects with type 2 diabetes. J Clin Endocrinol Metab. 2003;88:3082-3089.

31. Linnebjerg H, Park S, Kothare P, et al. Effect of exenatide on gastric emptying and relationship to postprandial glycemia in type 2 diabetes. Regul Pept. 2008;151:123-129.

32. Meier JJ, Gallwitz B, Salmen S, et al. Normalization of glucose concentrations and deceleration of gastric emptying after solid meals during intravenous glucagon-like peptide1 in patients with type 2 diabetes. J Clin Endocrinol Metab. 2003;88:2719-2725.

33. Toft-Nielsen MB, Madsbad S, Holst JJ. Continuous subcutaneous infusion of glucagon-like peptide 1 lowers plasma glucose and reduces appetite in type 2 diabetic patients. Diabetes Care. 1999;22: 1143-1999.

34. Moretto TJ, Milton DR, Ridge TD, et al. Efficacy and tolerability of exenatide monotherapy over 24 weeks in antidiabetic drug-naïve patients with type 2 diabetes: A randomized, doubleblind, placebo-controlled, parallel-group study. Clin Ther. 2008;30: $1448-1460$.

35. Drucker DJ, Buse JB, Taylor K, et al. Exenatide once weekly versus twice daily for the treatment of type 2 diabetes: a randomized, open-label, non-inferiority study. Lancet. 2008;372:1240-1250.

36. Buse JB, Henry RR, Han J, et al. Effects of exenatide (Exendin-4) on glycemic control over 30 weeks in sulfonylurea-treated patients with type 2 diabetes. Diabetes Care. 2004;27:2628-2635.

37. DeFronzo RA, Ratner RE, Han J, et al. Effects of exenatide (Exendin-4) on glycemic control and weight over 30 weeks in metformin-treated patients with type 2 diabetes. Diabetes Care. 2005; 28:1092-1100.

38. Kendall DM, Riddle MC, Rosenstock J, et al. Effects of exenatide (Exendin-4) on glycemic control over 30 weeks in patients with type 2 diabetes treated with metformin and a sulfonylurea. Diabetes Care. 2005;28:1083-1091.

39. Blonde L, Klein EJ, Han J, et al. Interim analysis of the effects of exenatide treatment on $\mathrm{A} 1 \mathrm{C}$, weight and cardiovascular risk factors over 82 weeks in 314 overweight patients with type 2 diabetes. Diabetes Obes Metab. 2006;8:436-447.

40. Ratner RE, Maggs D, Nielsen LL, et al. Long-term effects of exenatide therapy over 82 weeks on glycaemic control and weight in over-weight metformin-treated patients with type 2 diabetes mellitus. Diabetes Obes Metab. 2006;8:419-428.

41. Buse JB, Klonoff DC, Nielsen LL, et al. Metabolic effects of two years of exenatide treatment on diabetes, obesity, and hepatic biomarkers in patients with type 2 diabetes: An interim analysis of data from the open-label, uncontrolled extension of three double-blind, placebo-controlled trials. Clin Ther. 2007;29:139-153.

42. Elkind-Hirsch K, Marrioneaux O, Bhushan M, et al. Comparison of single and combined treatment with exenatide and metformin on mestrual cyclicity in overweight women with polycystic ovary syndrome. J Clin Endocrinol Metab. 2008;93:2670-2678.

43. Pinelli NR, Cha R, Brown MB, Jaber LA. Addition of thiazolidinedione or exenatide to oral agents in type 2 diabetes: a meta-analysis. The Annals of Pharmacotherapy. 2008;42:1541-1551. 
44. Zinman B, Hoogwerf BJ, Garcia SD, et al. The effect of adding exenatide to a thiazolidinediones in suboptimally controlled type 2 diabetes. Ann Intern Med. 2007;146:477-485.

45. Heine RJ, Van Gaal LF, Johns D, et al. Exenatide versus insulin glargine in patients with suboptimally controlled type 2 diabetes. Ann Intern Med. 2005;143:559-569.

46. Boye KS, Matza LS, Oglesby A, et al. Patient-reported outcomes in a trial of exenatide and insulin glargine for the treatment of type 2 diabetes. Health Qual Life Outcomes. 2006;4:80.

47. Nauck MA, Duran S, Kim D, et al. A comparison of twice-daily exenatide and biphasic insulin aspart in patients with type 2 diabetes who were suboptimally controlled with sulfonylurea and metformin: a non-inferiority study. Diabetologia 2007;50:259-267.

48. Glass LC, Qu Y, Lenox S, et al. Effects of exenatide versus insulin analogues on weight change in subjects with type 2 diabetes: a pooled post-hoc analysis. Curr Med Res Opin. 2008;24:639-644.
49. Fineman MS, Shen LZ, Taylor K, et al. Effectiveness of progressive dose-escalation of exenatide (exendin-4) in reducing dose-limiting side effects in subjects with type 2 diabetes. Diabetes Metab Res Rev. 2004;20:411-417.

50. U.S. Food and Drug Administration. Postmarketing reviews: Byetta and acute pancreatitis. FDA Drug Safety Newsletter. 2008;1(2).

51. Byetta (exenatide). In: Fleming T, Murray L, editors. Drug Topics Redbook. Montvale, NJ: Thomson PDR; 2009.

52. Minshall ME, Oglesby AK, Wintle ME, et al. Estimating the longterm cost effectiveness of exenatide in the United States: an adjunctive treatment for type 2 diabetes mellitus. Value Health. 2008; $11: 22-33$

\section{Publish your work in this journal}

Drug Design, Development and Therapy is an international, peerreviewed open-access journal that spans the spectrum of drug design and development through to clinical applications. Clinical outcomes, patient safety, and programs for the development and effective, safe, and sustained use of medicines are a feature of the journal, which has also been accepted for indexing on PubMed Central. The manuscript management system is completely online and includes a very quick and fair peer-review system, which is all easy to use. Visit http://www.dovepress.com/testimonials.php to read real quotes from published authors.

\footnotetext{
Submit your manuscript here: http://www.dovepress.com/drug-design-development-and-therapy-journal
} 